\title{
Favorabilidade climática para a ferrugem do eucalipto no estado do Paraná
}

\author{
Karen Christiane Bora ${ }^{1}$, Gabriela Scheinpflug Brito ${ }^{2}$, Celso Garcia Auer ${ }^{3}$, Álvaro Figueredo dos Santos ${ }^{3}$, Marcos \\ Silveira Wrege ${ }^{3}$
}

${ }^{1}$ Bióloga, Mestre em Engenharia Florestal, Secretaria do Estado da Educação do Paraná, Curitiba, PR; ${ }^{2}$ Universidade do Contestado, Canoinhas, SC, ${ }^{3}$ Embrapa Florestas, CEP 319, 83411-000 Colombo, PR.; Parte da Dissertação de mestrado do primeiro autor, apresentada à Universidade Federal do Paraná.

Autor para correspondência: Celso Garcia Auer (celso.auer@embrapa.br.)

Data de chegada: 29/07/2014. Aceito para publicação em: 26/08/2015.

$10.1590 / 0100-5405 / 2015$

\section{RESUMO}

Bora, K.C.; Brito, G.S.; Auer, C.G.; Santos, A.F dos.; Wrege, M. S. Favorabilidade climática para a ferrugem do eucalipto no estado do Paraná. Summa Phytopathologica, v.42, n.1, p.24-42, 2016.

A cultura do eucalipto no estado do Paraná, Brasil, fornece matériaprima para a produção de celulose, carvão, madeira tratada e madeira serrada. Dentre as principais doenças fúngicas, destaca-se a ferrugem causada por Puccinia psidii. Diversas formas de controle desta doença podem ser apontadas, destacando-se o plantio de clones resistentes em locais com condições climáticas menos favoráveis à ocorrência da doença. A escolha de locais com baixos riscos climáticos pode ser feita por meio do zoneamento. Assim, o objetivo deste estudo foi desenvolver um zoneamento da favorabilidade climática para a ferrugem do Eucalyptus, no estado do Paraná, com base na temperatura e no período de molhamento foliar para a germinação de urediniósporos e infecção por P. psidii. Estas informações foram utilizadas em modelos para a geração dos mapas mensais de distribuição da doença, conforme a favorabilidade à ocorrência da doença: 'altamente favorável', 'favorável', 'pouco favorável' e 'desfavorável'. Os mapas gerados foram validados pelo confronto com os pontos de ocorrência natural da ferrugem no estado do Paraná. Concluiu-se que as estações do ano mais favoráveis à ocorrência da doença foram a primavera e o verão e a menos favorável foi o inverno. A região central do estado, na zona de transição entre o clima tropical do Norte e o temperado do Sul, é mais favorável à ocorrência da ferrugem e que, a região Sul e a Norte, são menos favoráveis por razões diferentes, em decorrência das baixas temperaturas e menor umidade, respectivamente.

Palavras-chave: Eucalyptus, Puccinia psidii, zoneamento fitossanitário.

\section{ABSTRACT}

Bora, K.C.; Brito, G.S.; Auer, C.G.; Santos, A.F dos.; Wrege, M.S. Climatic favorability for eucalyptus rust in Paraná State, Brazil. Summa Phytopathologica, v.42, n.1, p.24-42, 2016.

The culture of eucalyptus in the state of Paraná, Brazil, provides raw materials for the production of cellulose, coal, treated wood and lumber. Among the major fungal diseases, rust caused by Puccinia psidii can be pointed out as the most important one. Several forms to control this disease can be cited, especially the planting of resistant clones in areas of climatic conditions less favorable to the occurrence of this disease. The choice for areas of low climatic risks can be made by means of climate zoning. Thus, the aim of this study was to develop a climate favorability zoning for Eucalyptus rust, in Paraná State, Brazil, based on temperature and leaf wetness duration for urediniospore germination and infection by $P$. psidii. These data were applied in models to produce monthly maps of the disease distribution, according to the favorability to the disease occurrence: 'highly favorable', 'favorable', 'scarcely favorable' and 'unfavorable'. The generated maps were validated by means of comparison with points of natural rust occurrence in Paraná State. It was concluded that spring and summer were the seasons most favorable to the disease, whereas winter was the least favorable season. The central region of the state, in the zone of transition between the tropical climate of the North and the temperate climate of the South, is more favorable to the occurrence of rust, and the South and the North regions are less favorable for different reasons, due to the low temperature and humidity, respectively.

Keywords: Eucalyptus, Puccinia psidii, phytosanitary zoning.

O eucalipto é a espécie florestal mais plantada no Brasil, com mais de 5,56 milhões de hectares em 2014, devido ao rápido crescimento, capacidade de regeneração após o corte e uso múltiplo de sua madeira (11). No estado do Paraná, a área ocupada por plantios de Eucalyptus nesse período foi de mais de 224 mil hectares. Além da produção de celulose, também é fonte de carvão vegetal para gerar energia e de madeira sólida usada em móveis, pisos, revestimentos, aplicações na construção civil e produção de óleos essenciais (11).

Uma das principais doenças do eucalipto é a ferrugem, causada por Puccinia psidii Winter, também encontrada em espécies arbóreas nativas da família Myrtaceae, parasitando mudas e árvores jovens e retardando o crescimento dos indivíduos severamente afetados (1, $11,20)$. O ataque às folhas jovens e brotações provoca deformações, prejudica a fotossíntese e reduz o crescimento das árvores, levando à queda da produtividade de plantios nos anos de maior severidade. Além disso, as perdas econômicas causados pelo fungo nos plantios de eucalipto podem ser consideráveis, dependendo do local, manejo silvicultural e da espécie ou da procedência plantada $(1,10)$

A ferrugem do eucalipto apresenta ampla distribuição no Brasil (9), ocorrendo principalmente nas regiões Sudeste e Nordeste. Na 
região Sul, pode ser encontrada nos três estados. O fungo ocorre praticamente em todos os continentes, principalmente em regiões tropicais e subtropicais $(3,6,17)$.

Os estudos das relações entre as condições climáticas e a ocorrência de doenças de plantas são importantes para a elaboração de programas de controle de pragas e de políticas públicas, visando a diminuição dos riscos (24). Assim, torna-se necessária a elaboração de zoneamentos de riscos climáticos, onde são indicadas zonas de menores riscos climáticos de ocorrência da doença e, portanto, onde o eucalipto pode ser plantado com riscos menores de ocorrer a ferrugem $(13,16,22)$.

O zoneamento de riscos climáticos pode reunir informações sobre as condições favoráveis à ocorrência da ferrugem e classificá-las em zonas de baixo, médio ou alto risco (13). O zoneamento de áreas de risco pode direcionar a indicação de espécies ou clones de eucalipto, em função do grau de suscetibilidade à ferrugem $(16,22)$.

O presente estudo teve o objetivo de gerar informações sobre a ocorrência da ferrugem do eucalipto no estado do Paraná, por meio de mapas de favorabilidade climática, os quais auxiliarão na recomendação de plantio do eucalipto em áreas com baixo risco de ocorrência da doença. $\mathrm{O}$ zoneamento da ferrugem do eucalipto permitirá a escolha das melhores regiões para plantio no Paraná, de acordo com a suscetibilidade dos materiais genéticos existentes.

\section{MATERIAL E MÉTODOS}

\section{Organização da base de dados para o trabalho no estado do Paraná}

Inicialmente, elaborou-se um banco de dados com pontos georreferenciados de ocorrência de P. psidii em Eucalyptus spp. e em espécies da família Myrtaceae no estado do Paraná. Estas informações foram obtidas no Laboratório de Patologia Florestal da Embrapa Florestas, Centro de Diagnóstico Marcos Enrietti (23), Emater e empresas do setor florestal. Para os locais com indicação de ocorrência de $P$. psidii, mas sem as coordenadas geográficas latitude e longitude, foi utilizada a coordenada do município em que foi identificada a ocorrência de P. psidii, usando-se informações do banco de dados do Centro de Referência em Informação Ambiental (CRIA) (5). Os dados de pontos de ocorrência de $P$. psidii foram usados para validação do zoneamento (Tabela 1).

Utilizou-se duas bases distintas de dados climáticos, uma para a temperatura do ar e outra para o período de molhamento foliar. Os dados climáticos usados da primeira base de dados pertencem à rede de estações meteorológicas existentes no estado do Paraná, com séries temporais de dados do Instituto Agronômico do Paraná (Iapar), Instituto Nacional de Meteorologia (Inmet) e Agência Nacional de Águas (ANA). Os cálculos foram baseados nas médias mensais, a partir de dados diários, para uma série de 1976 a 2005 (24). Wrege et al. (26) analisaram a completude, a consistência e os erros da base e fizeram as correções necessárias. Optou-se por usar essa base de dados porque é mais completa e possui melhor resolução espacial. Foi elaborada a partir de uma base de dados diários, contando com mais de 90 estações meteorológicas com séries completas e mais de 500 estações pluviométricas em toda a região sul do Brasil, incluindo o Uruguai e, no caso da precipitação, o estado de São Paulo, para a interpolação dos dados. Essa base não possui dados do período de molhamento foliar.

A segunda base de dados climáticos foi usada para calcular o período de molhamento foliar e, diferentemente do que ocorreu com a temperatura do ar, foram usadas séries temporais de dados do período histórico de 1961 a 1990. Os valores foram elaborados por Hamada et al. (12) para períodos mensais, que verificou a completude, a consistência e os erros da série. Essa série tem menor resolução espacial e foi disponibilizada pelo Instituto Nacional de Pesquisas Espaciais (INPE) e pelo Inmet. Hamada et al. (12) selecionaram os melhores modelos e calcularam a média entre os modelos. Alvares et al. (2) apresentaram uma modelagem para a geração de valores de períodos mensais de molhamento foliar, em escala de país (Brasil todo). No presente estudo, no entanto, foi usado o modelo de Hamada et al. (12), por ser mais adequado à escala de trabalho em nível estadual.

\section{Elaboração dos mapas básicos utilizados no zoneamento de} riscos climáticos

Foram utilizadas duas técnicas diferentes de mapeamento para as diferentes variáveis climáticas. Os mapas de temperatura foram elaborados usando-se a técnica da regressão linear múltipla, enquanto que os mapas do período de molhamento foliar foram elaborados pela técnica da krigagem ordinária, de acordo com os princípios da geoestatística.

As regressões para os mapas de temperatura do ar foram elaboradas considerando-se como variáveis independentes a altitude e as coordenadas geográficas latitude e longitude. Como variáveis dependentes ficaram as temperaturas médias do ar e as médias mensais das temperaturas mínimas do ar.

O modelo da equação de regressão linear múltipla usada foi:

$$
\mathrm{y}=\alpha+\beta \mathrm{x} \text { latitude }+\chi \mathrm{x} \text { longitude }+\delta \mathrm{x} \text { altitude, }
$$

Em que y é a temperatura do $\operatorname{ar}\left({ }^{\circ} \mathrm{C}\right) ; \alpha$ é o coeficiente linear; $\beta$ é o coeficiente angular correspondente à latitude, $\chi$ é o coeficiente angular correspondente à longitude e $\delta$ é o coeficiente angular correspondente à altitude, de acordo com Wrege et al. (26). Os valores de $\alpha, \beta, \chi \mathrm{e}$ $\delta$ encontram-se nas tabelas 2 , com os coeficientes das temperaturas médias mensais, e 3, com os coeficientes das médias mensais das temperaturas mínimas.

Os mapas das variáveis climáticas foram elaborados em sistemas de informações geográficas (SIG), usando o programa ArcGIS 10, na escala 1: 250.000, utilizando o modelo MNT de superfície do terreno do GTOPO30 (24), além dos modelos de latitude e de longitude (26). Os mapas de temperatura do ar foram gerados em formato 'raster'.

O método de interpolação do período de molhamento foliar foi $\mathrm{o}$ da krigagem ordinária, sendo escolhido o modelo exponencial e foram elaborados mapas na escala 1:250.000. Os mapas de período de molhamento foliar foram exportados para o formato 'vetor'. Não foi possível mapear o período de molhamento foliar pela técnica da regressão. Os coeficientes de determinação apresentaram valores muito baixos e os melhores resultados foram obtidos pela técnica da krigagem.

As sobreposições entre os diferentes mapas foram feitas em sistemas de informações geográficas (SIG), por meio de intersecção entre camadas. Para esse fim, primeiramente todas foram unificadas no formato 〈vetor〉. Como resultado destas operações, foram gerados os seguintes mapas: 1) médias das temperaturas mínimas do ar e período de molhamento foliar noturno de quatro ou seis horas para a germinação e 2) temperaturas médias e período de molhamento foliar de quatro ou seis horas para a infecção, resultando em mapas com as seguintes classes de favorabilidade para o desenvolvimento de $P$. psidii: 'altamente favorável', 'favorável', 'pouco favorável' e 'desfavorável'. 
Tabela 1. Localização da ocorrência da ferrugem causada por Puccinia psidii em Eucalyptus e outros hospedeiros no estado do Paraná.

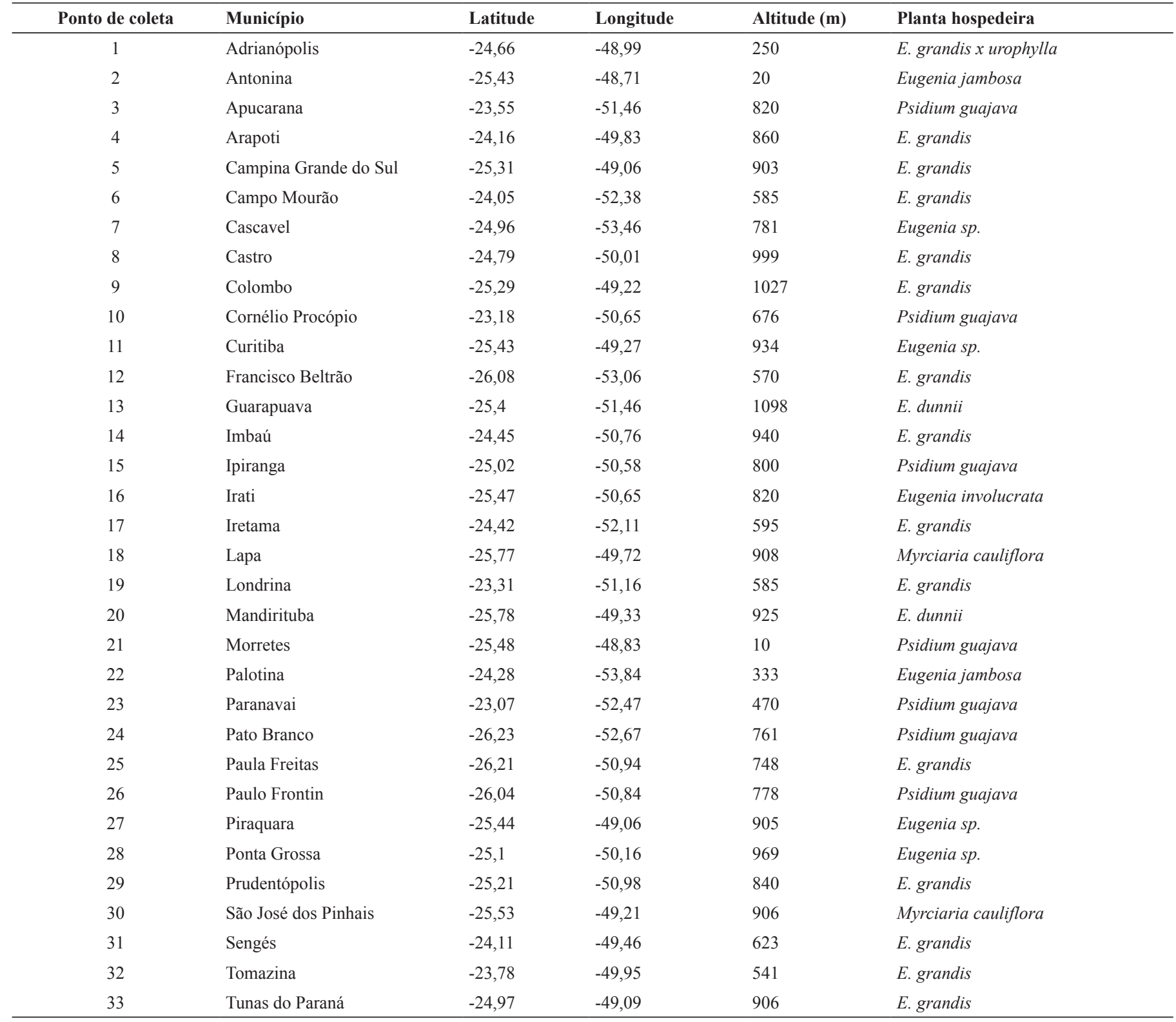

Tabela 2. Coeficientes das equações de regressão utilizados para o mapeamento das temperaturas médias do $\operatorname{ar}\left({ }^{\circ} \mathrm{C}\right)$.

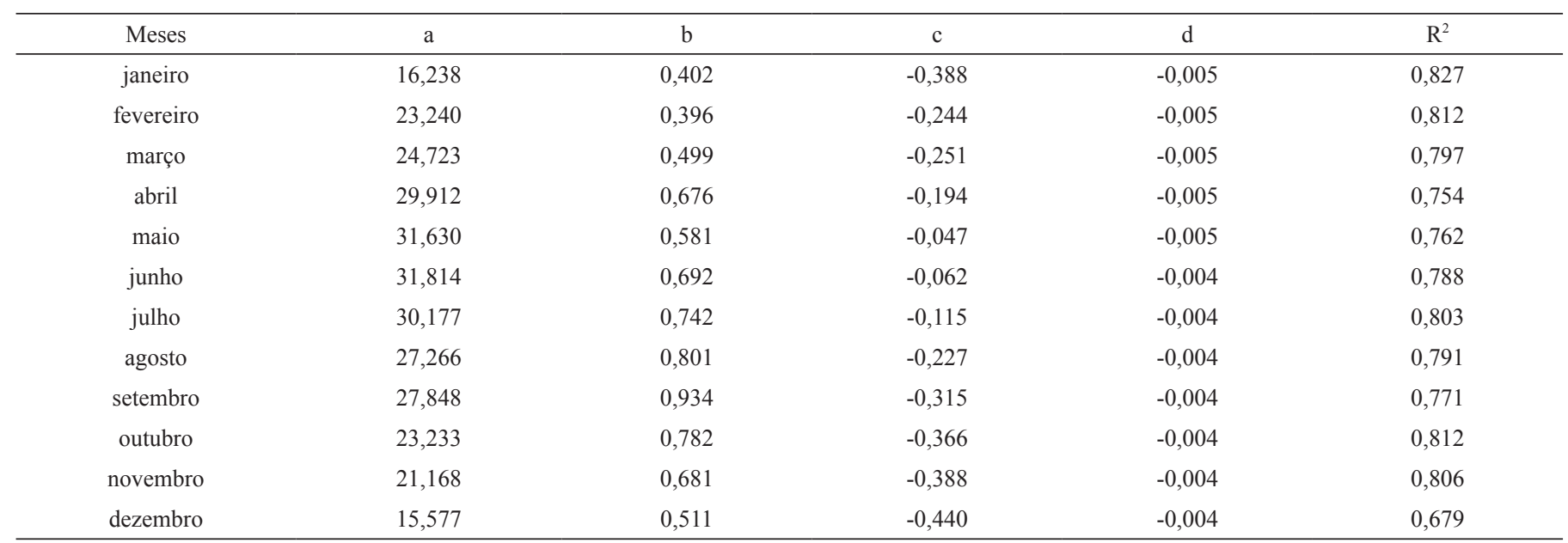


Tabela 3. Coeficientes das equações de regressão utilizados para o mapeamento das médias das temperaturas mínimas do ar ( ${ }^{\circ} \mathrm{C}$ ).

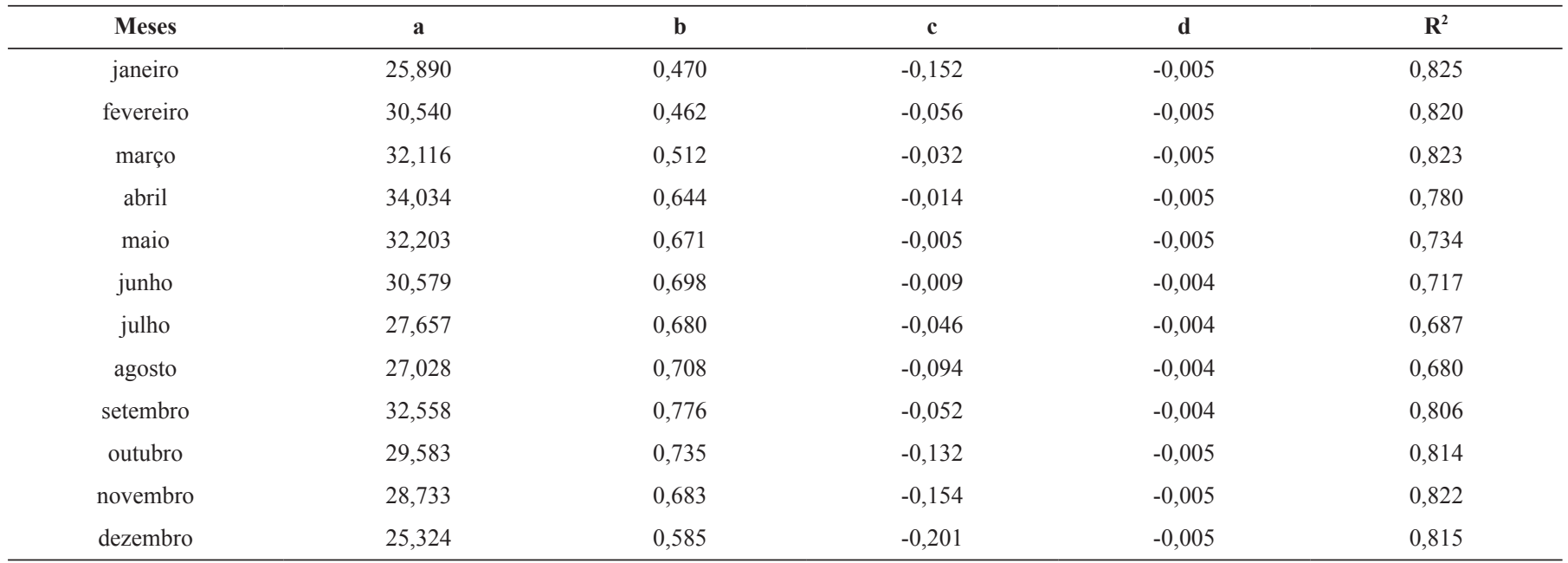

Elaboração do zoneamento de riscos climáticos para a ferrugem do eucalipto no estado do Paraná

$\mathrm{O}$ zoneamento da ferrugem do eucalipto baseou-se no ajuste de dois parâmetros epidemiológicos conhecidos da doença, que são a germinação de urediniósporos de $P$. psidii e a infecção pelo fungo.

As informações referentes à faixa de temperatura para a germinação de urediniósporos de $P$. psidii foram obtidos dos trabalhos feitos por Ferreira (8) e Cruz et al. (7). O primeiro autor verificou que as melhores temperaturas para a germinação de urediniósporos são de 15 e $20^{\circ} \mathrm{C}$, enquanto que o segundo autor considerou que a germinação ótima ocorre entre 20 e $25^{\circ} \mathrm{C}$. Baseado nesses duas informações, definiu-se $15-25{ }^{\circ} \mathrm{C}$ como a faixa favorável de temperatura, dividindo-a em duas classes distintas: 'altamente favorável' e 'favorável'. Ainda foram criadas outras duas classes marginais situadas fora desta faixa ótima de temperatura: 'pouco favorável' e 'desfavorável' (Tabela 4).

A temperatura favorável para a infecção do eucalipto por $P$. psidii baseou-se em estudos de Ruiz (20) e Masson (14). Assim, definiu-se como favorável o intervalo de temperatura de $18-25^{\circ} \mathrm{C}$, dividindo-o em duas classes distintas: 'altamente favorável'e 'favorável'. Fora desta faixa, foram criadas outras duas classes marginais: 'pouco favorável' e 'desfavorável' (Tabela 4).

A partir dos estudos de temperatura favorável à infecção feitos por Ruiz (20) e Masson (15), definiu-se o período de molhamento foliar. O período de molhamento foliar mínimo necessário para a ocorrência da doença pode ser de 6 horas (20), mas altos índices de infecção podem ser registrados com apenas 3 horas de molhamento foliar (15). Por haver divergências, foram elaborados dois cenários: o primeiro, onde o limite para o desenvolvimento do fungo e da doença seria de 4 horas de molhamento foliar e, o segundo, com 6 horas. Assim, foram comparados os cenários sobre a distribuição da doença, a fim de verificar qual é o período de molhamento foliar que melhor explica a ocorrência da doença no estado do Paraná (Tabela 4).

\section{RESULTADOS E DISCUSSÃO}

\section{Distribuição geográfica da ferrugem do eucalipto no estado do Paraná}

A partir da análise dos pontos de ocorrência da ferrugem, verificouse que a doença ocorre praticamente em todo o estado do Paraná, concentrando-se nas regiões Leste, Norte e Central (Tabela 1). A região Leste apresentou 12 ocorrências, sendo 5 em eucalipto, seguido pela região Norte, com 8 ocorrências (4 em eucalipto), e a região Central, com 7 ocorrências ( 5 em eucalipto). Das 33 ocorrências registradas de ferrugem, 16 foram em Eucalyptus (E. grandis, E. dunnii e híbrido E. urograndis) e 17 em outras mirtáceas (gêneros Eugenia, Psidium e Myrciaria).

As regiões descritas como favoráveis correspondem às regiões fitogeográficas com climas submontano e subtropical úmidos na maior parte do ano (4), que favorecem a germinação dos urediniósporos e a infecção das plantas. Essas regiões também apresentam maior número de registro de ferrugem, pela presença de plantios comerciais formados com eucaliptos (E. grandis, E. dunnii, E. saligna e híbrido E. urograndis) (18), considerados suscetíveis (1).

A ferrugem foi encontrada desde localidades com baixas altitudes, 20 metros, até acima de 1000 metros, mostrando grande variação

Tabela 4. Classes de favorabilidade para ocorrência da ferrugem do eucalipto em função dos intervalos de temperatura média e período de molhamento foliar, considerando a germinação e infecção por urediniósporos de Puccinia psidii.

\begin{tabular}{lcccc}
\hline Classes de favorabilidade & $\begin{array}{c}\text { Temperatura média }\left({ }^{\circ} \mathbf{C}\right) \text { de } \\
\text { germinação }\end{array}$ & $\begin{array}{c}\text { Temperatura } \\
\text { média }\left({ }^{\circ} \mathbf{C}\right) \text { de infecção }\end{array}$ & $\begin{array}{c}\text { Molhamento foliar } \\
\mathbf{4} \text { horas }\end{array}$ & $\begin{array}{c}\text { Molhamento foliar } \\
\mathbf{6} \text { horas }\end{array}$ \\
\hline Altamente favorável & 15 a 25 & 18 a 25 & $<4$ & $<6$ \\
Favorável & 15 a 25 & 18 a 25 & $<$ a 18 & $<4$ \\
Pouco favorável & 10 a 15 & $<15$ & $*$ & $* 6$ \\
Desfavorável & $<10$ & $*$ & $*$ \\
\hline
\end{tabular}

*O período de molhamento foliar não influencia. 
altitudinal na distribuição espacial, o que indica elevada capacidade de adaptação ecológica do fungo às diferentes regiões bioclimáticas. A adaptação pode estar relacionada à ocorrência de $P$. psidii em praticamente todas as regiões do Brasil, conforme descrito por Ferreira (9).

A ferrugem também foi registrada em locais do Norte do estado do Paraná com ocorrência de estiagens frequentes. A ausência de chuvas pode influenciar negativamente na ocorrência da doença, em alguns meses do ano, por reduzir o período de molhamento foliar à noite. Outro fator que também está associado à ocorrência da doença são as baixas temperaturas, principalmente no sul do estado do Paraná, por não criarem as condições climáticas favoráveis à germinação dos urediniósporos e a infecção.

Zoneamento de riscos climáticos com base na temperatura de germinação de urediniósporos de $\boldsymbol{P}$. psidii

Com base na análise dos mapas mensais (Figuras 1 a 12), verificouse a existência de variação das classes de favorabilidade climática à germinação de $P$. psidii ao longo do ano.

As condições climáticas mais favoráveis à germinação dos urediniósporos ocorreram no período entre outubro e abril (Figuras 1, 2, $3,4,10,11,12$ ) sendo que entre dezembro e março (Figuras 1, 2, 3, 12) ocorreu aumento das áreas classificadas como 〈altamente favoráveis〉 e 〈favoráveis〉. São meses de maior pluviosidade e maior período de molhamento foliar e que, portanto, podem favorecer a germinação e o início da infecção.

Maio a setembro foi o período em que houve redução das áreas classificadas como 〈favorável〉 e 〈pouco favorável〉 à ocorrência da ferrugem no eucalipto (Tabela 5), devido às baixas temperaturas e menor volume de precipitação, variáveis que interferem na germinação dos urediniósporos.

Nos meses de março, abril e maio ainda ocorrem condições favoráveis de temperatura (Figuras 3, 4 e 5), mas o volume de chuvas é menor, e por isso o uso do período de molhamento foliar de quatro horas é o mais indicado, por apresentar maior área favorável à ocorrência de P. psidii.

Analisando os dois períodos de molhamento foliar noturno, verificou-se que o período de 4 horas foi o que apresentou maior favorabilidade à ocorrência de ferrugem ao longo do ano no estado do Paraná (Figuras 1 a 12). O período de 4 horas também permitiu explicar a presença de $P$. psidii em áreas do Norte do estado, onde ocorrem estiagens com maior frequência, inclusive no verão. Alguns estudos determinaram que o tempo de 4 horas é suficiente para ocorrer a germinação dos urediniósporos de $P$. psidii, podendo iniciar até com menos de 2 horas $(9,19)$.

Maior área ocorreu no estado utilizando-se quatro horas de período de molhamento foliar para a classe 'altamente favorável', entre 84,3 e 99,8\%. Maior área também foi verificada utilizando seis horas de molhamento foliar para a classe 'favorável', entre 24,3 e $70,4 \%$, o mesmo ocorrendo para as classes 'pouco favorável' e 'desfavorável'. Neste último caso, não foi verificada diferença entre 4 ou 6 horas (Tabela 4).

Zoneamento climático com base na temperatura de infecção por $P$. psidii

O período em que a temperatura apresentou maior favorabilidade à ocorrência da ferrugem foi entre outubro e abril (Figuras 1, 2, 3, 4, $10,11,12)$, com período de molhamento foliar de 4 horas, quando comparado à germinação. Consequentemente, o período em que as temperaturas tornaram-se desfavoráveis foi entre maio e setembro.
Resultados praticamente inversos foram apresentados por Moraes et al. (16), que estudaram a favorabilidade de ocorrência da ferrugem em eucalipto nos estado do Espírito Santo e Sul da Bahia com base na infecção. Naquele estudo, verificou-se que o período de maior favorabilidade à ocorrência da ferrugem foi compreendido entre maio e novembro.

Analisando-se os mapas e verificando a distribuição espacial da ocorrência da doença, verificou-se que o melhor período de molhamento foliar para a infecção de $P$. psidii foi de 4 horas. Os períodos mais favoráveis à infecção foram a primavera e o verão, considerando-se 4 horas de molhamento foliar, e a primavera e o outono, com 6 horas de molhamento foliar. A estação menos favorável para germinação dos urediniósporos e infecção do eucalipto por $P$. psidii foi o inverno.

Segundo Ruiz et al. (21), as folhas e as brotações novas aparecem com maior frequência nas plantas mais jovens de eucalipto, com até dois anos. Nas regiões mais frias da região Sul do país, as brotações novas ocorrem mais frequentemente no verão. No inverno, ocorre redução no crescimento e, consequentemente, menores chances de tecidos do hospedeiro (folhas e brotações) tornarem-se favoráveis à infecção (16). Desse modo, apesar de ocorrer molhamento foliar, o que favorece o desenvolvimento da ferrugem, a favorabilidade torna-se menor.

Ruiz (20) estudou a ocorrência da ferrugem em mudas de dois gêneros diferentes: E. grandis e Syzigium jambos, procedentes da África do Sul. O isolado de P. psidii utilizado nesses ensaios foi obtido de folhas de $E$. cloeziana, infectado naturalmente, no município de Teixeira de Freitas, Bahia. As mudas, após inoculadas, foram submetidas às temperaturas de $10,15,20,25$ e $30^{\circ} \mathrm{C}$ e aos tempos de água livre de $6,12,24,36$ e 48 horas (no escuro). Após estes períodos de câmara úmida, as mudas passaram para câmara de crescimento, a $21+1$ ${ }^{\circ} \mathrm{C}, 60$ a $80 \%$ de UR e 12 horas de fotoperíodo, até a avaliação dos resultados. Os maiores índices de infecção ocorreram à 20 e $25^{\circ} \mathrm{C}$, e o número de soros aumentou conforme aumentou o tempo de água livre na superfície foliar. Porém, a $20^{\circ} \mathrm{C}$, com 6 horas de água livre, produziu-se um número de soros considerado favorável à infecção. As condições climáticas favoráveis consideradas por Ruiz (20) podem ser encontradas principalmente no verão, na região Sul do país.

Os picos de infecção da ferrugem verificados por Ruiz (20) ocorreram em uma época do ano em que as médias das temperaturas mínimas em Teixeira de Freitas, estado da Bahia, variaram entre 17 e $20^{\circ} \mathrm{C}$, e a média das temperaturas máximas, entre 25 e $28^{\circ} \mathrm{C}$. Apesar da diferença regional, se comparado ao estado do Paraná, pode se dizer que existe similaridade entre as temperaturas favoráveis.

Masson (15) analisou a ferrugem do eucalipto em áreas localizadas no extremo Sul do estado da Bahia, por meio de dados diários de temperatura e período de molhamento foliar, em plantios comerciais de clones de E. grandis e do híbrido E. urograndis. Através de avaliações de incidência e severidade, o autor determinou um índice de infecção de ferrugem diário, visando uma análise comparativa entre doença x clima (região) x clone. Os índices foram consolidados em valores médios mensais para cada região de plantio. $\mathrm{O}$ autor observou que em uma das áreas avaliadas, no mês de julho, foi registrada uma média de molhamento foliar de 3,7 horas e uma média de temperatura máxima de $22,6{ }^{\circ} \mathrm{C}$, onde o índice de infecção manteve-se alto. Em outra área, também no mês de julho, foi registrada uma média de molhamento foliar de 3 horas e uma temperatura máxima de $25,3{ }^{\circ} \mathrm{C}$, e a infecção manteve-se também em nível alto. Desta forma, pode-se inferir que períodos de molhamento foliar próximos de 4 horas e temperaturas na faixa de 22 a $25^{\circ} \mathrm{C}$ são considerados favoráveis à infecção por $P$. psidii.

No presente estudo, comparou-se os índices de infecção por $P$. psidii para 4 e 6 horas de molhamento foliar e concluiu-se que as 
Período de molhamento foliar para ocorrência da germinação
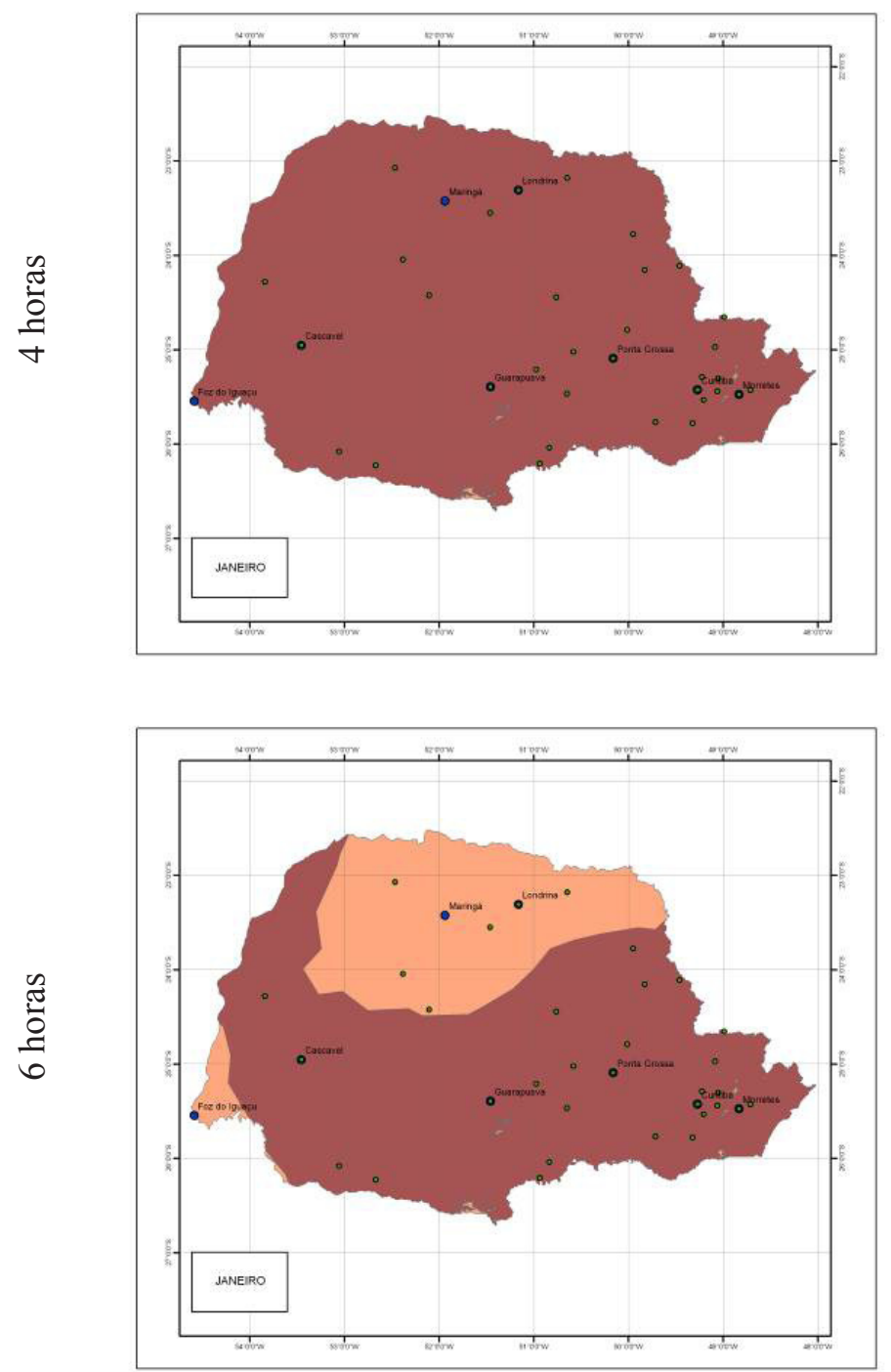

Período de molhamento foliar para ocorrência da infecção
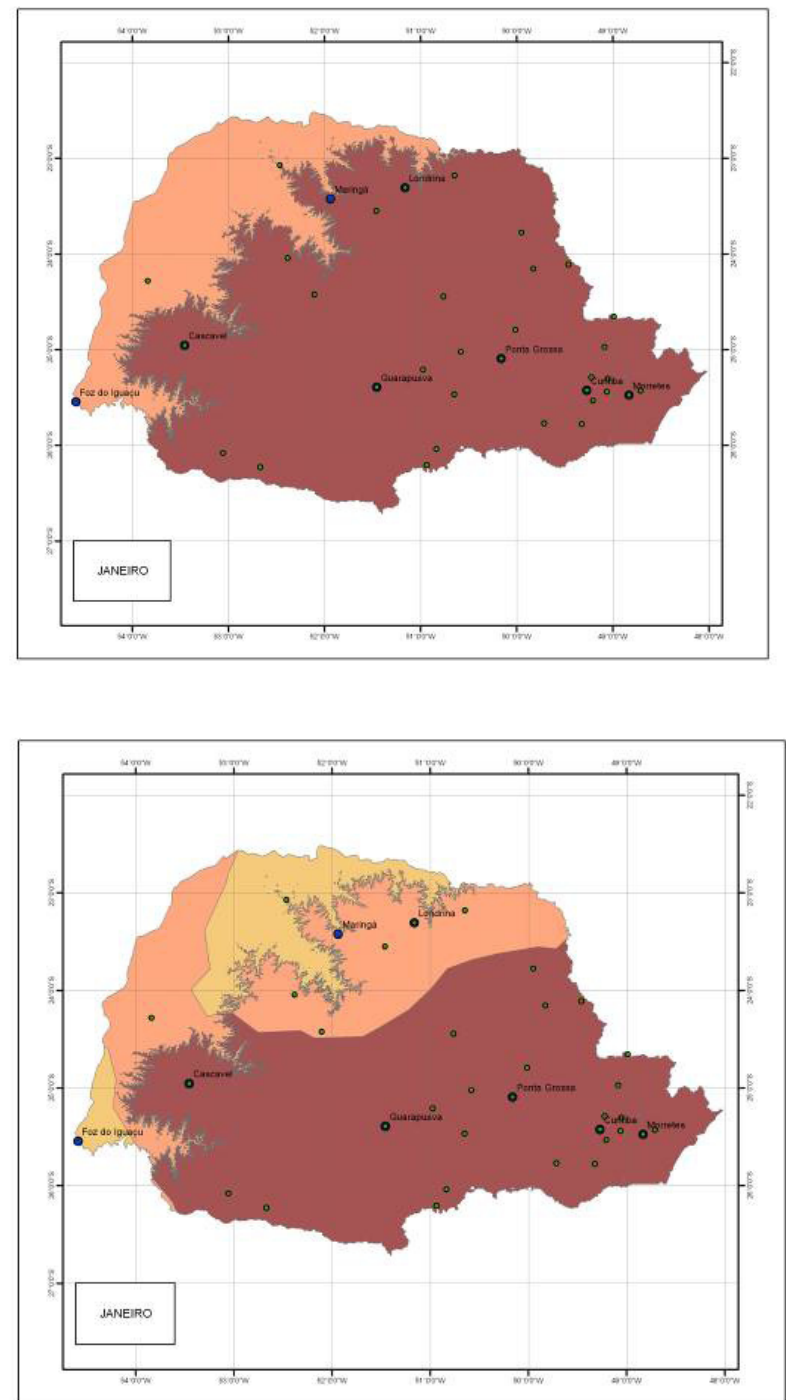

Legenda:

Altamente favorável

Favorável

Pouco favorável

Figura 1. Favorabilidade climática da ferrugem do eucalipto no estado do Paraná com base na germinação de urediniósporos de Puccinia psidii e infecção sob períodos de molhamento foliar de quatro e seis horas. Janeiro. 
Período de molhamento foliar para ocorrência da germinação
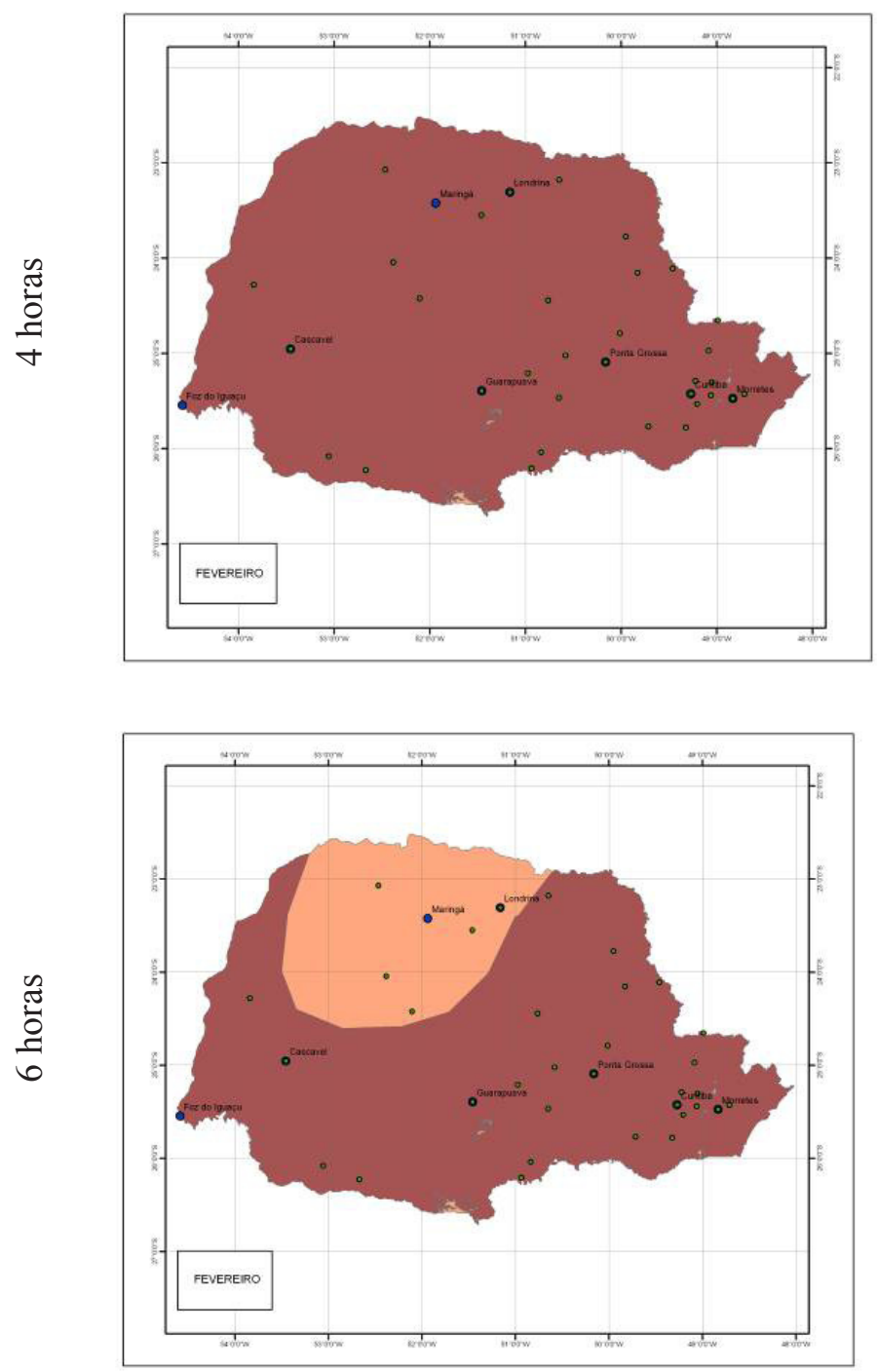

Período de molhamento foliar para ocorrência da infecção
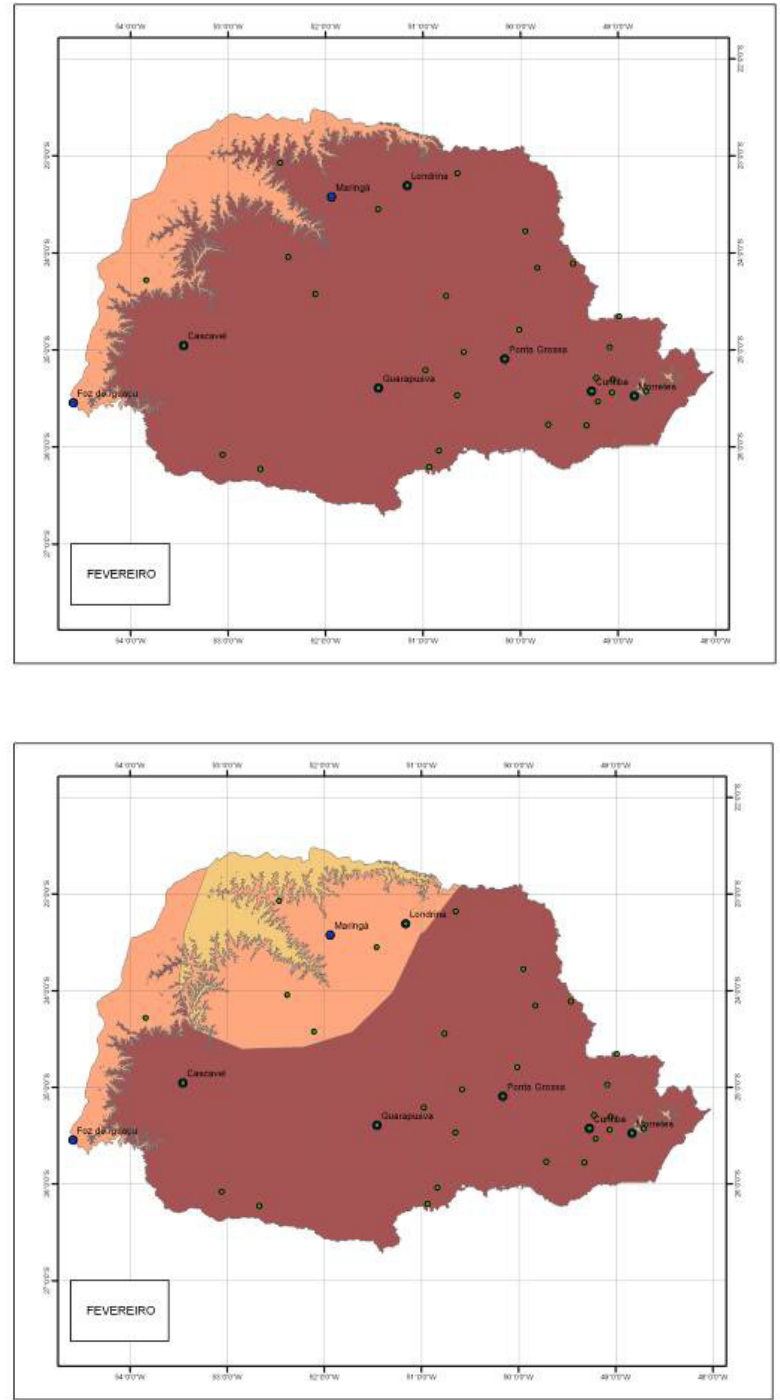

Legenda:

Altamente favorável

Favorável

Pouco favorável

Figura 2. Favorabilidade climática da ferrugem do eucalipto no estado do Paraná com base na germinação de urediniósporos de Puccinia psidii e infecção sob períodos de molhamento foliar de quatro e seis horas. Fevereiro. 
Período de molhamento foliar para ocorrência da germinação
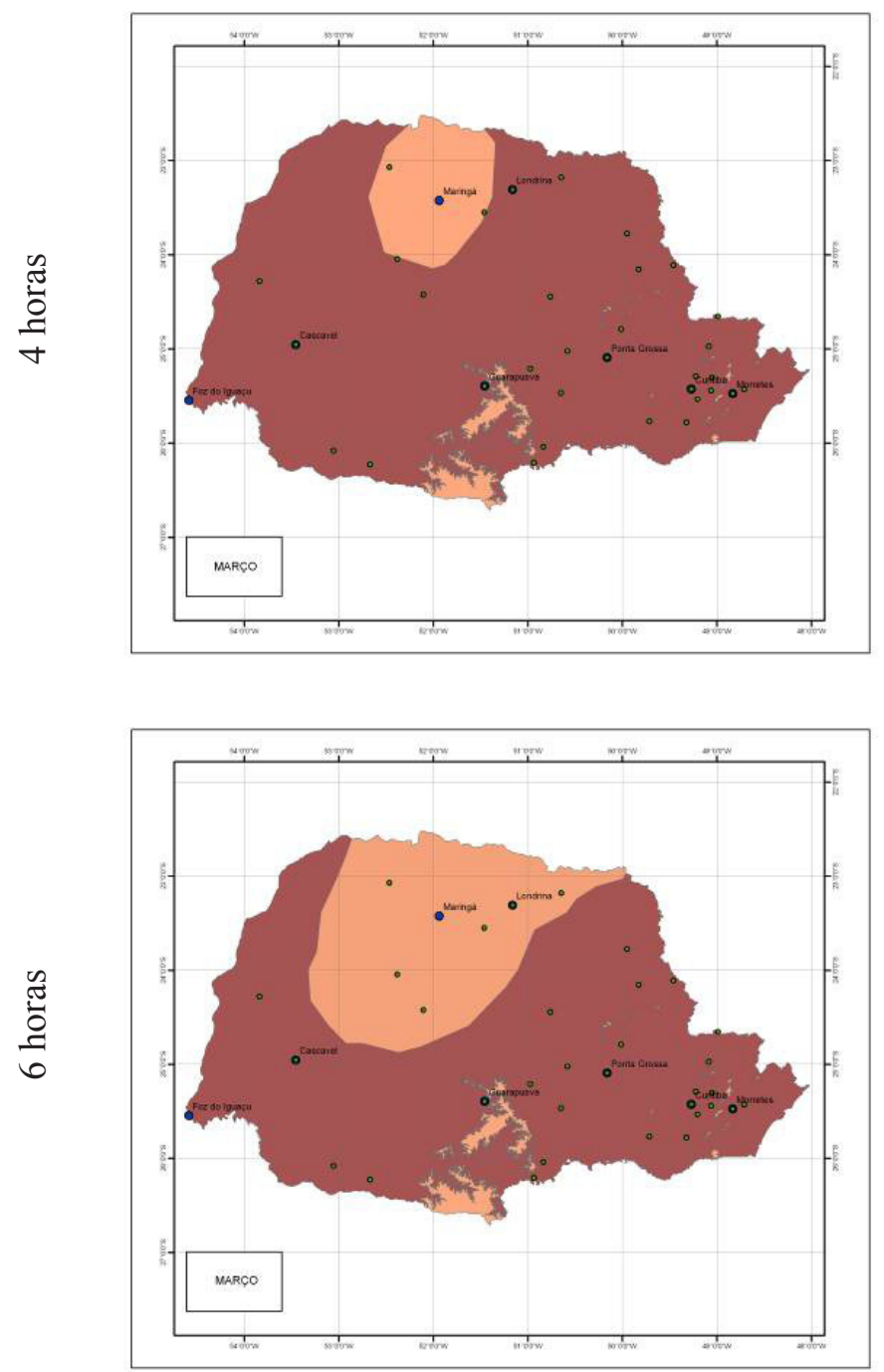

Período de molhamento foliar para ocorrência da infecção
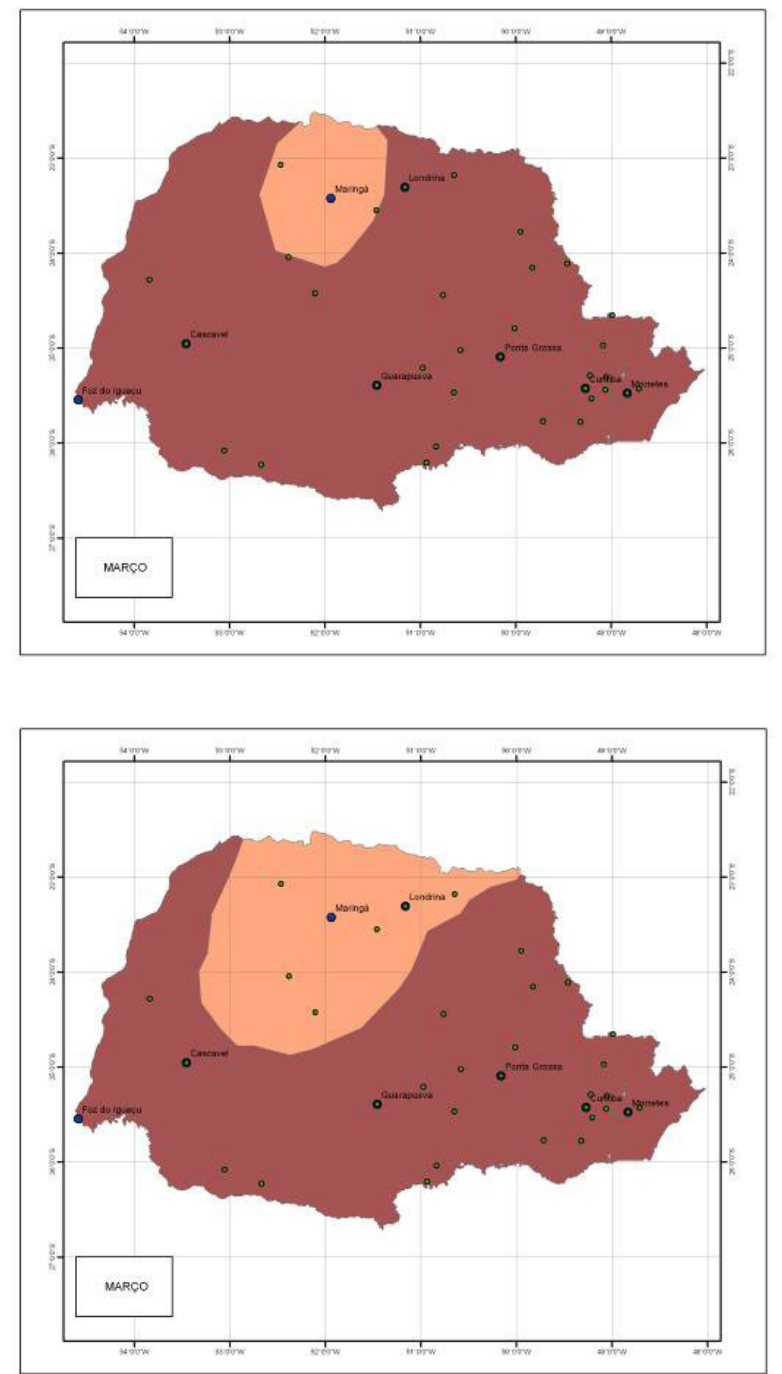

Legenda:

Altamente favorável

Favorável

Figura 3. Favorabilidade climática da ferrugem do eucalipto no estado do Paraná com base na germinação de urediniósporos de Puccinia psidii e infecção sob períodos de molhamento foliar de quatro e seis horas. Março. 
Período de molhamento foliar para ocorrência da germinação
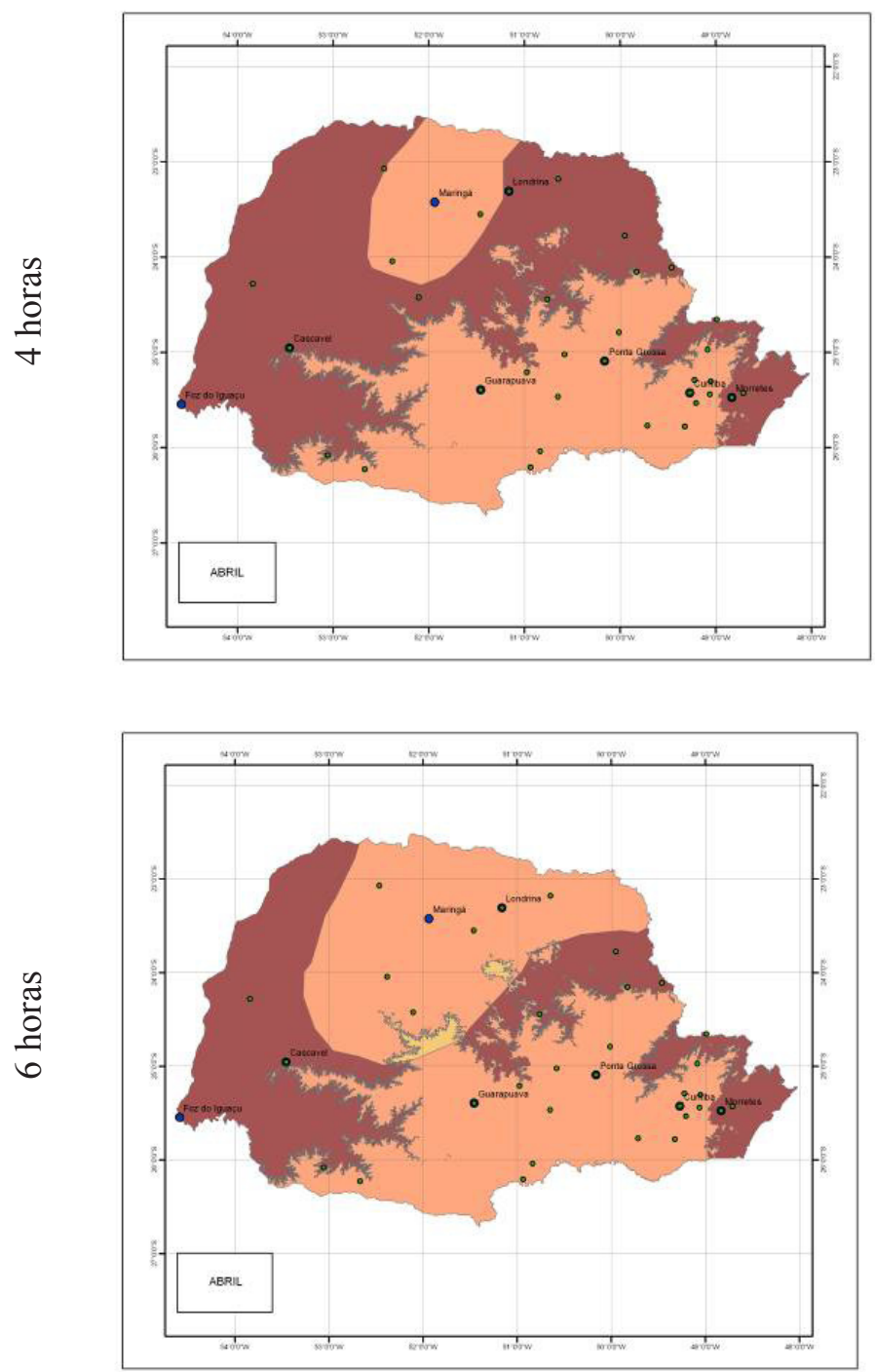

Período de molhamento foliar para ocorrência da infecção
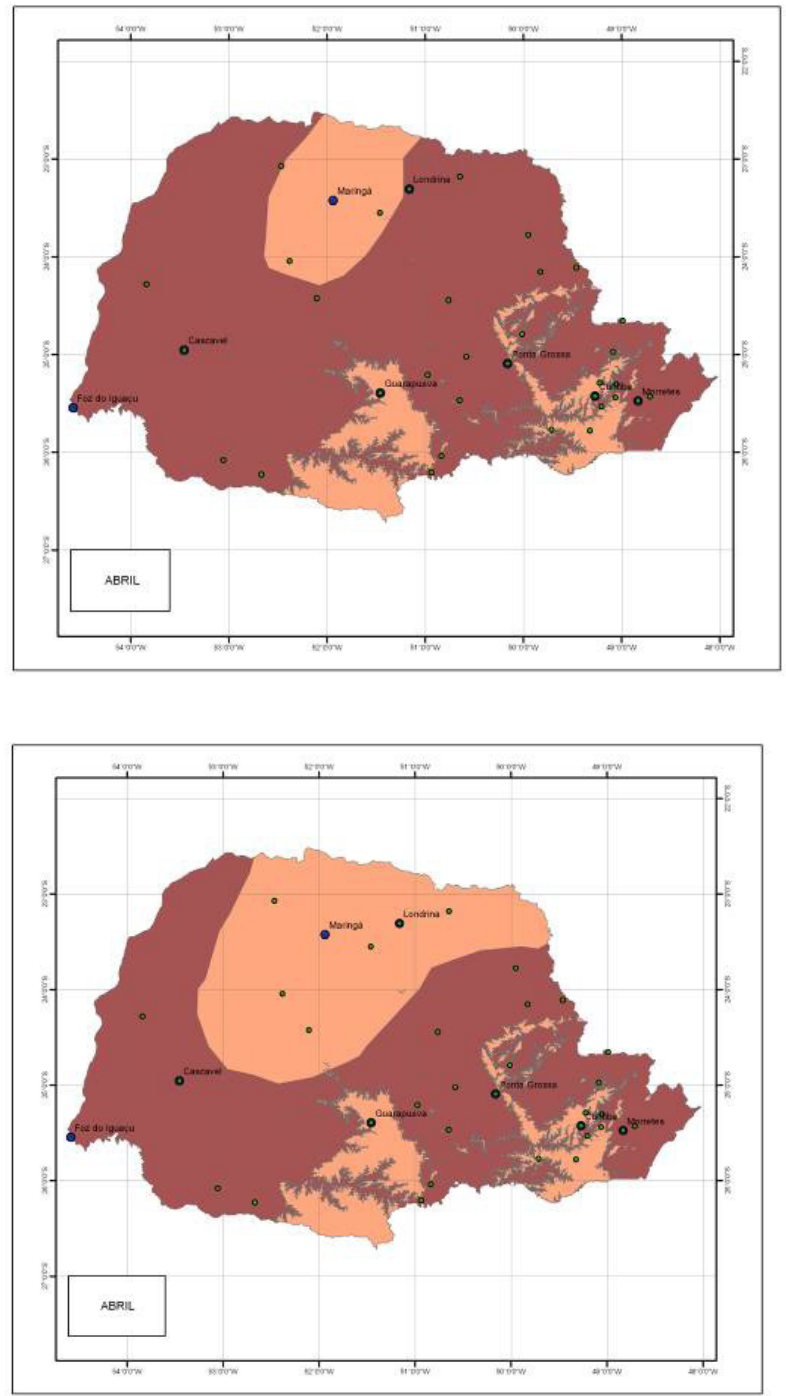

Legenda:

Altamente favorável

Favorável

Pouco favorável

Figura 4. Favorabilidade climática da ferrugem do eucalipto no estado do Paraná com base na germinação de urediniósporos de Puccinia psidii e infecção sob períodos de molhamento foliar de quatro e seis horas. Abril. 
Período de molhamento foliar para ocorrência da germinação
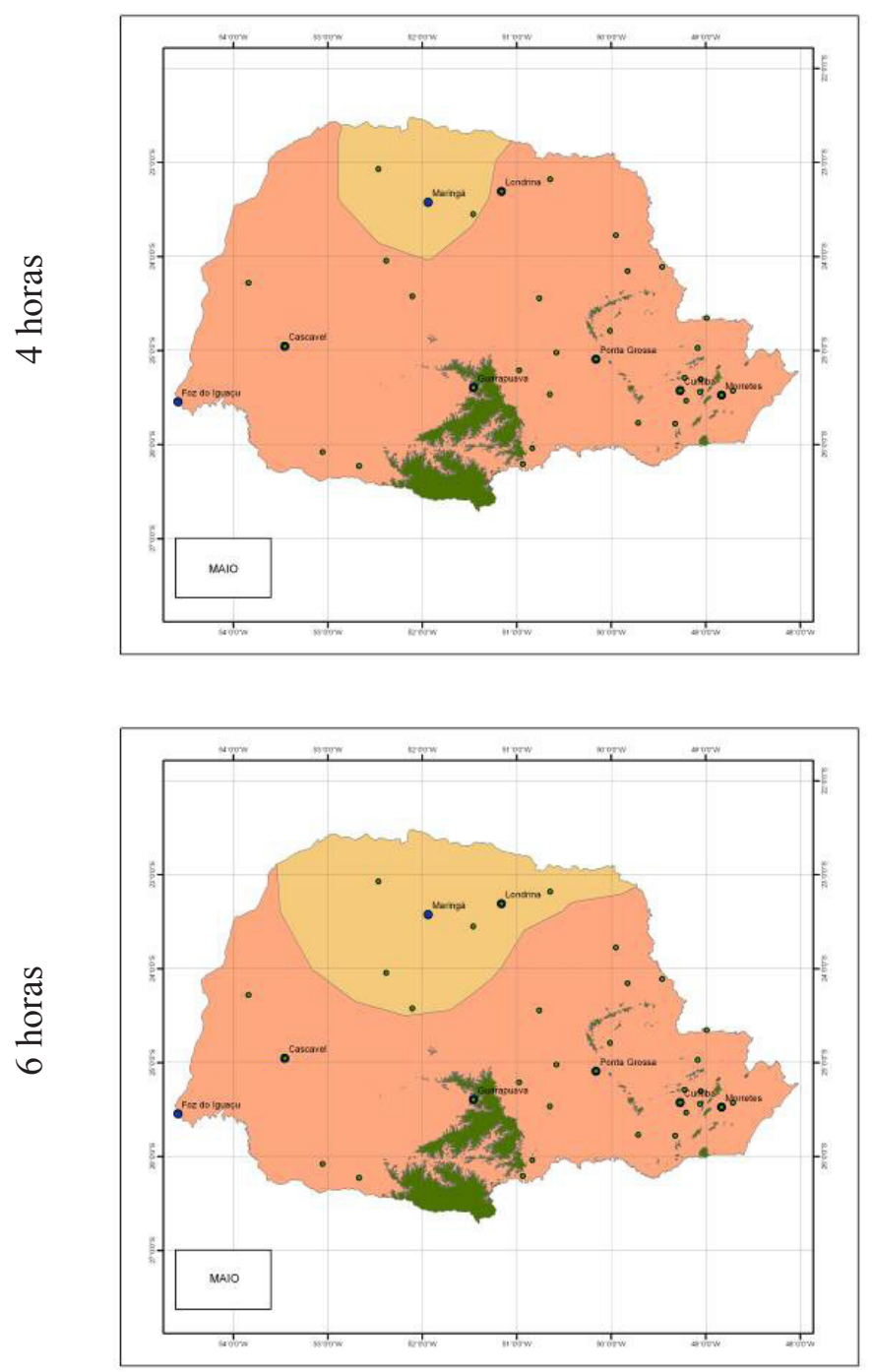

Período de molhamento foliar para ocorrência da infecção
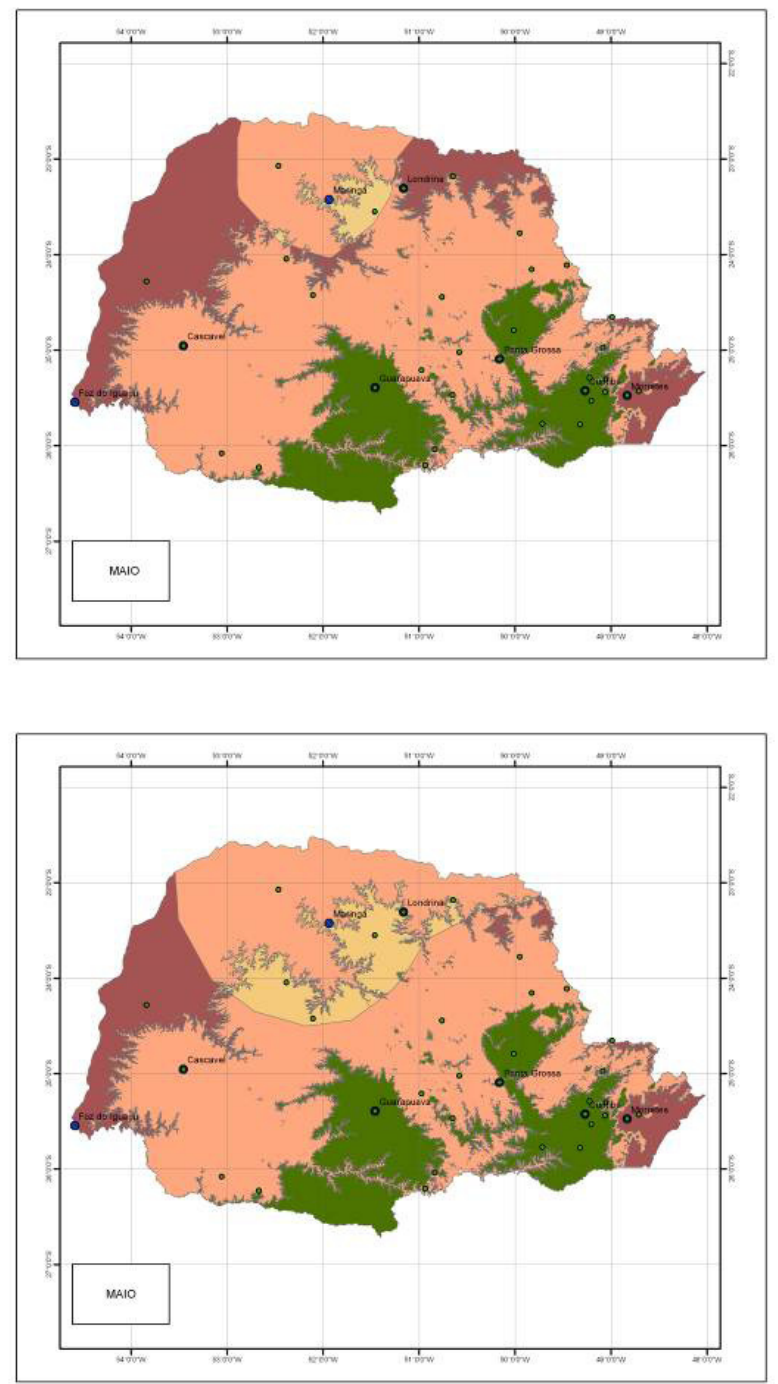

Legenda:

Altamente favorável

Favorável

Pouco favorável

Desfavorável

Figura 5. Favorabilidade climática da ferrugem do eucalipto no estado do Paraná com base na germinação de urediniósporos de Puccinia psidii e infecção sob períodos de molhamento foliar de quatro e seis horas. Maio. 
Período de molhamento foliar para ocorrência da germinação
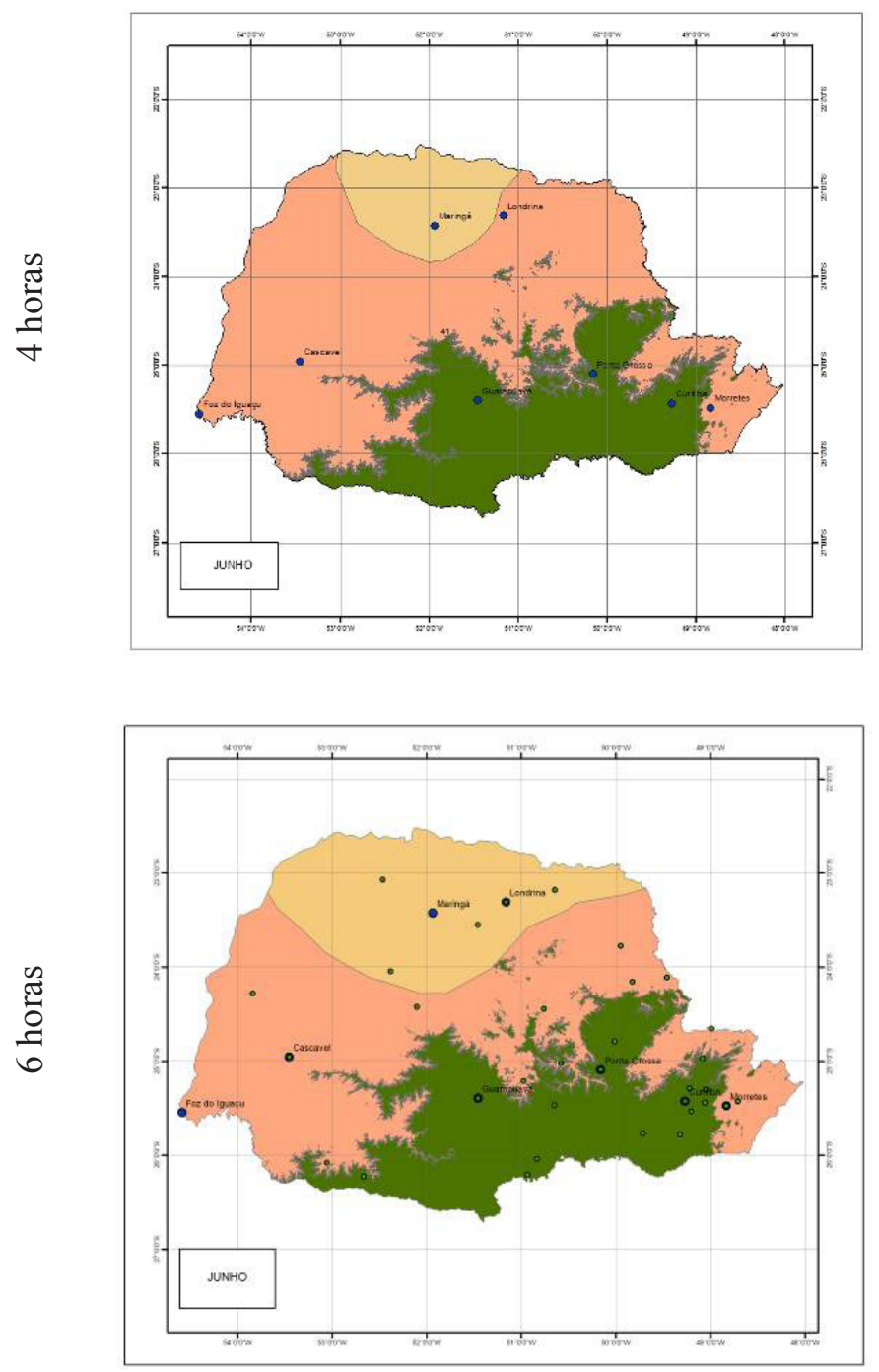

Período de molhamento foliar para ocorrência da infecção
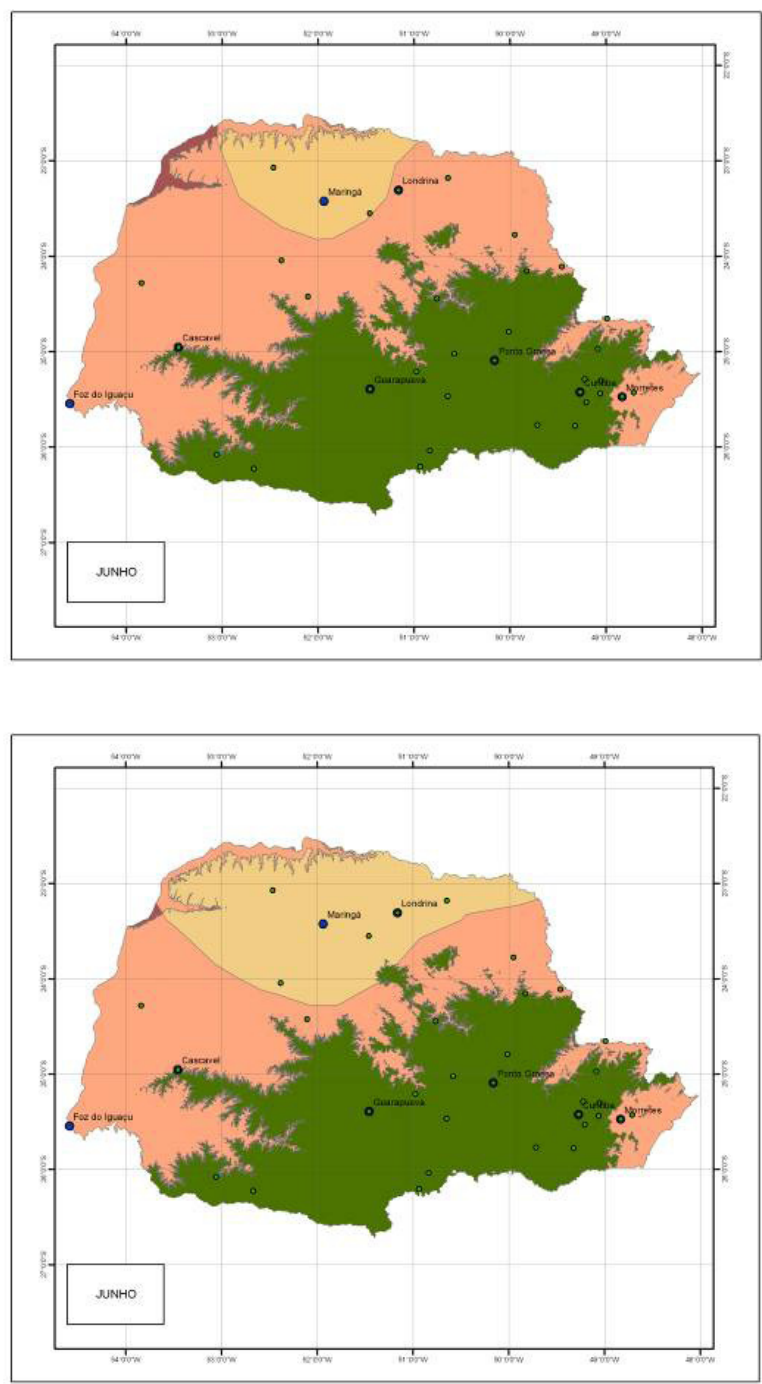

Legenda:

Altamente favorável

Favorável

Pouco favorável

Desfavorável

Figura 6. Favorabilidade climática da ferrugem do eucalipto no estado do Paraná com base na germinação de urediniósporos de Puccinia psidii e infecção sob períodos de molhamento foliar de quatro e seis horas. Junho. 
Período de molhamento foliar para ocorrência da germinação
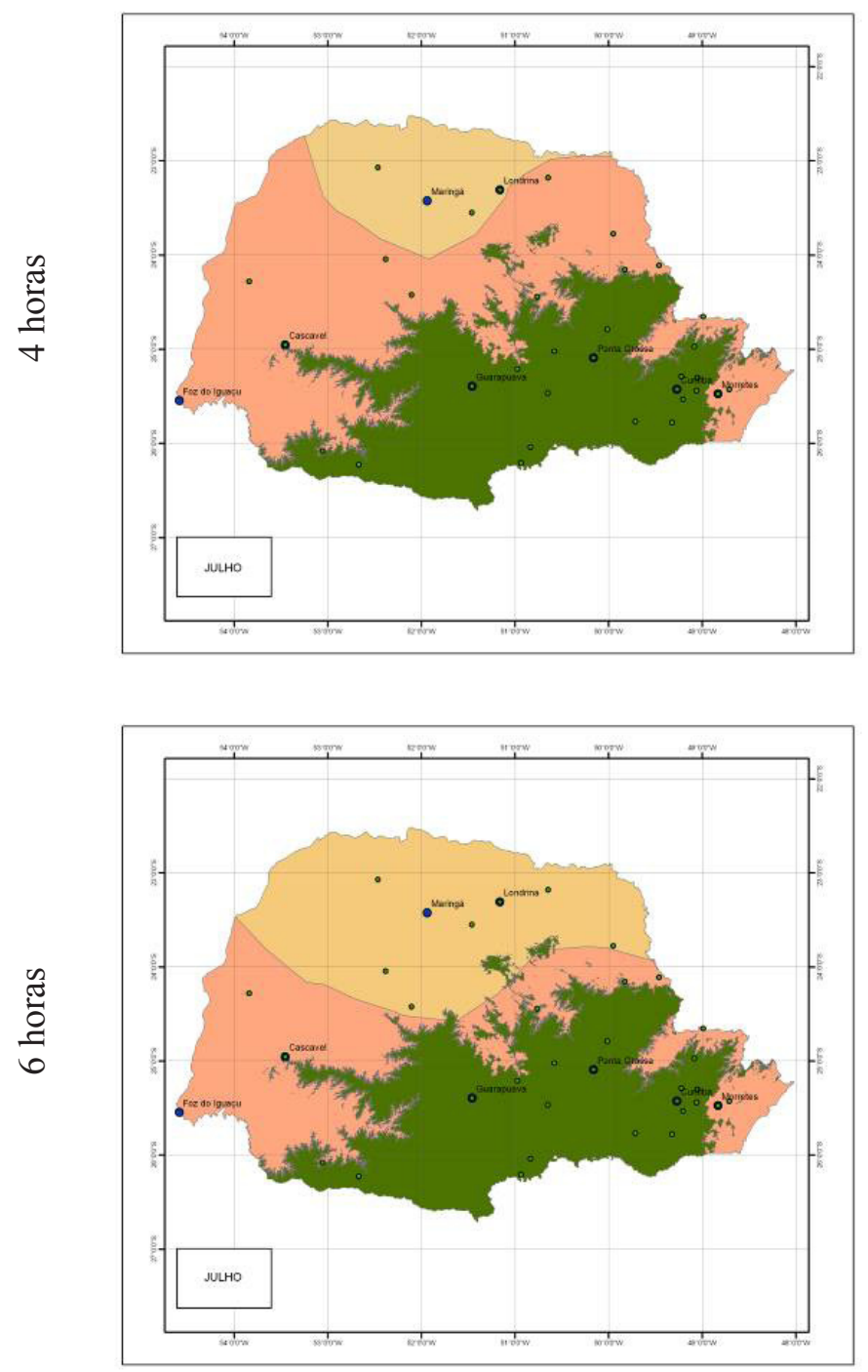

Período de molhamento foliar para ocorrência da infecção
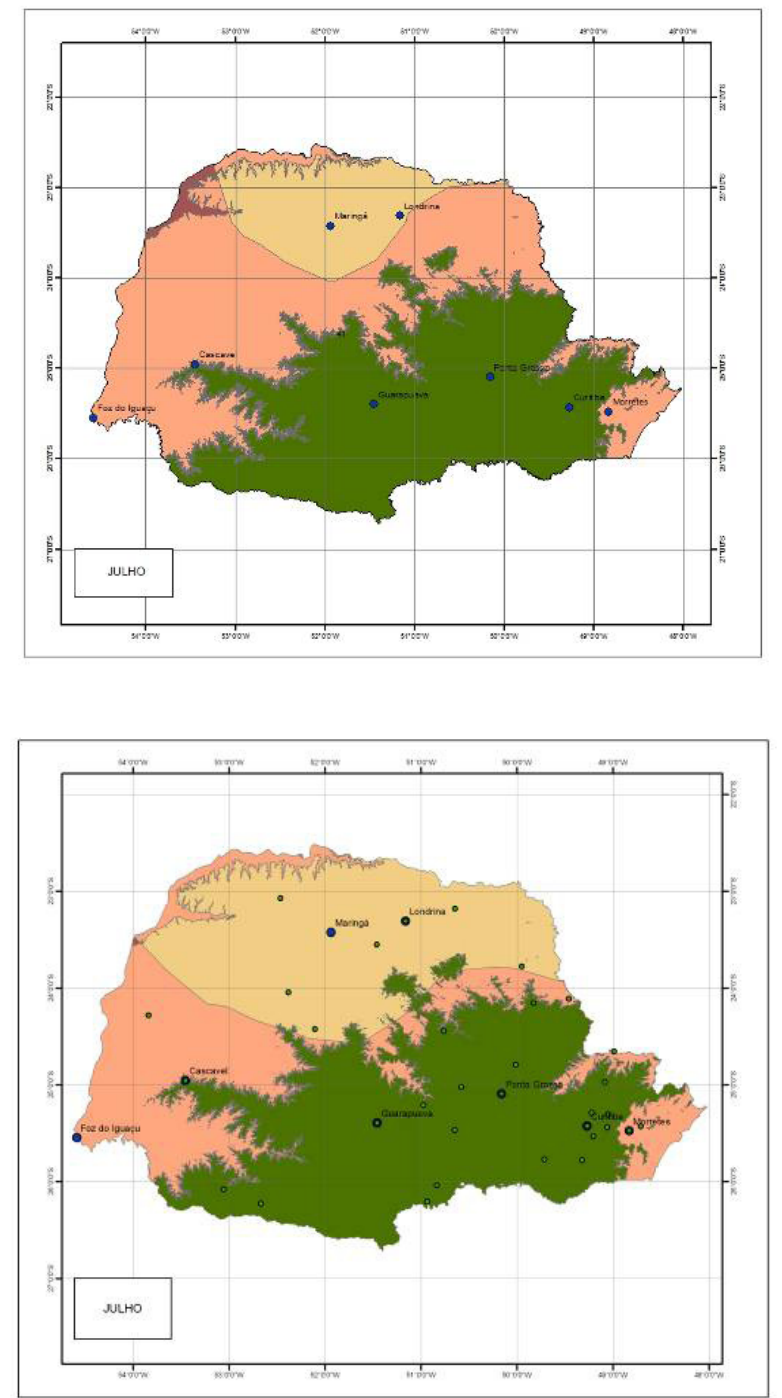

Legenda:

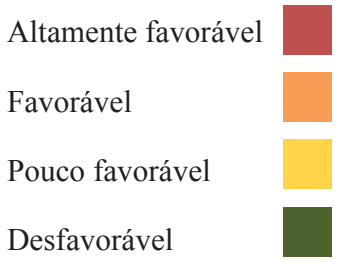

Figura 7. Favorabilidade climática da ferrugem do eucalipto no estado do Paraná com base na germinação de urediniósporos de Puccinia psidii e infecção sob períodos de molhamento foliar de quatro e seis horas. Julho. 
Período de molhamento foliar para ocorrência da germinação
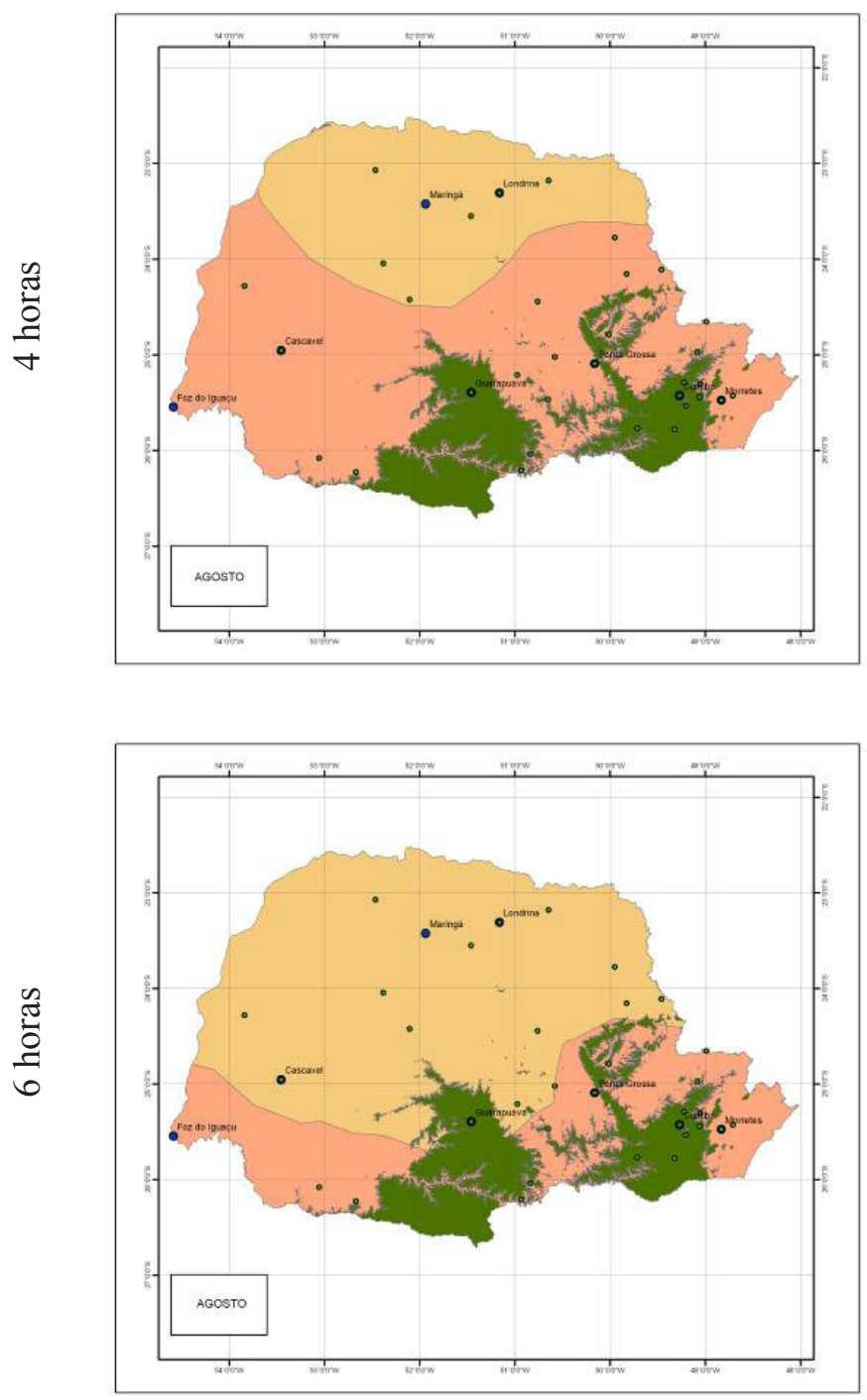

Período de molhamento foliar para ocorrência da infecção
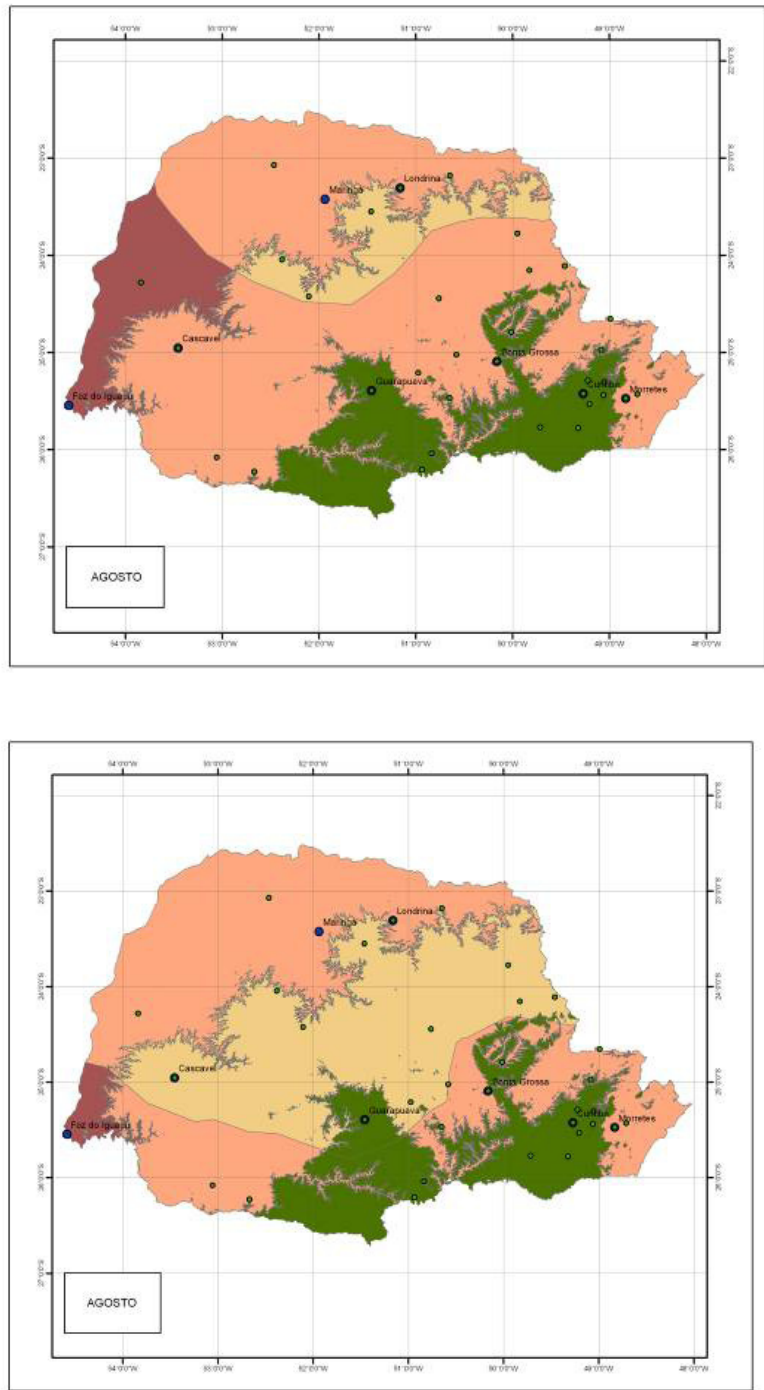

Legenda:

Altamente favorável

Favorável

Pouco favorável

Desfavorável

Figura 8. Favorabilidade climática da ferrugem do eucalipto no estado do Paraná com base na germinação de urediniósporos de Puccinia psidii e infecção sob períodos de molhamento foliar de quatro e seis horas. Agosto. 
Período de molhamento foliar para ocorrência da germinação
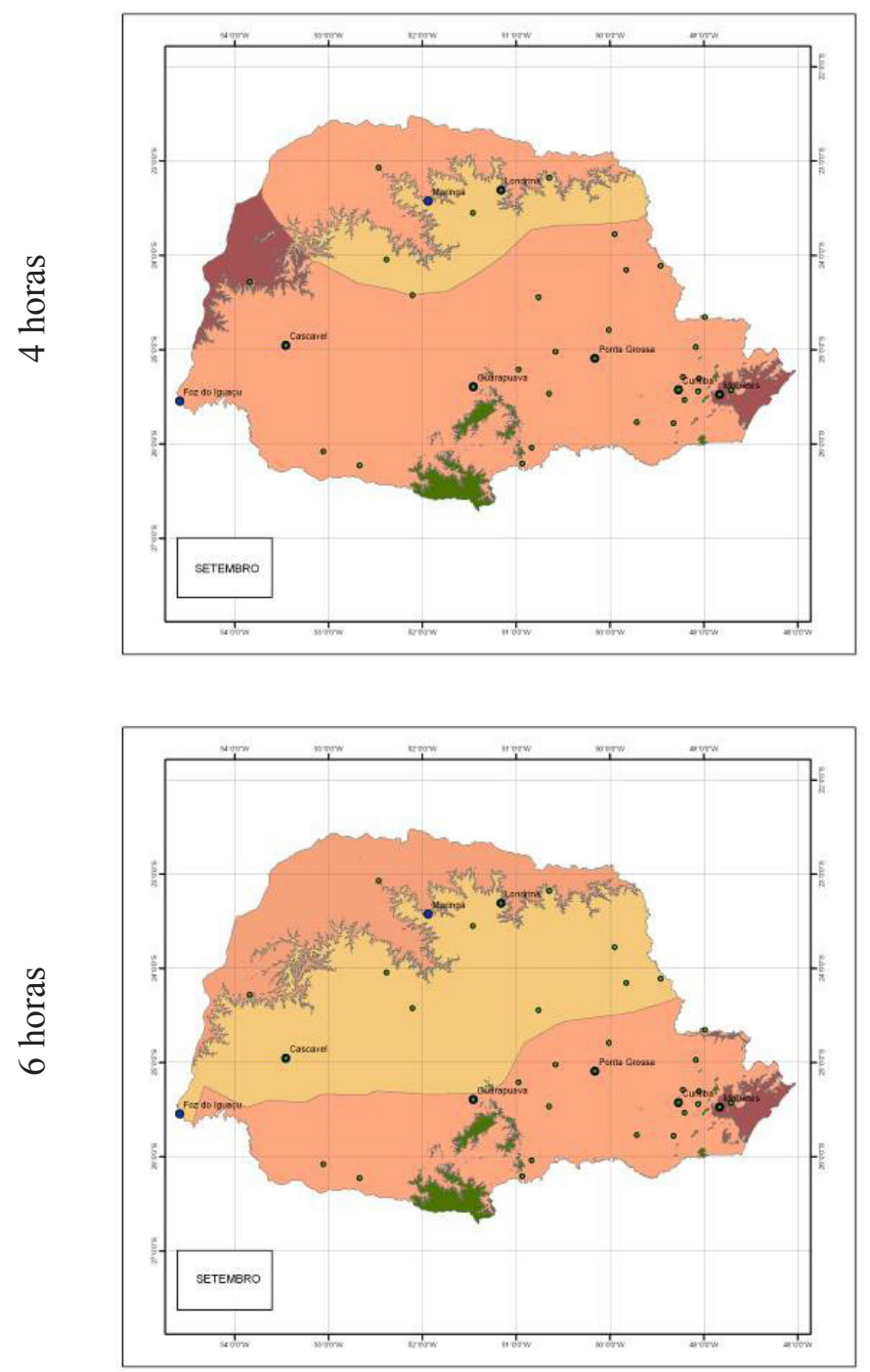

Período de molhamento foliar para ocorrência da infecção
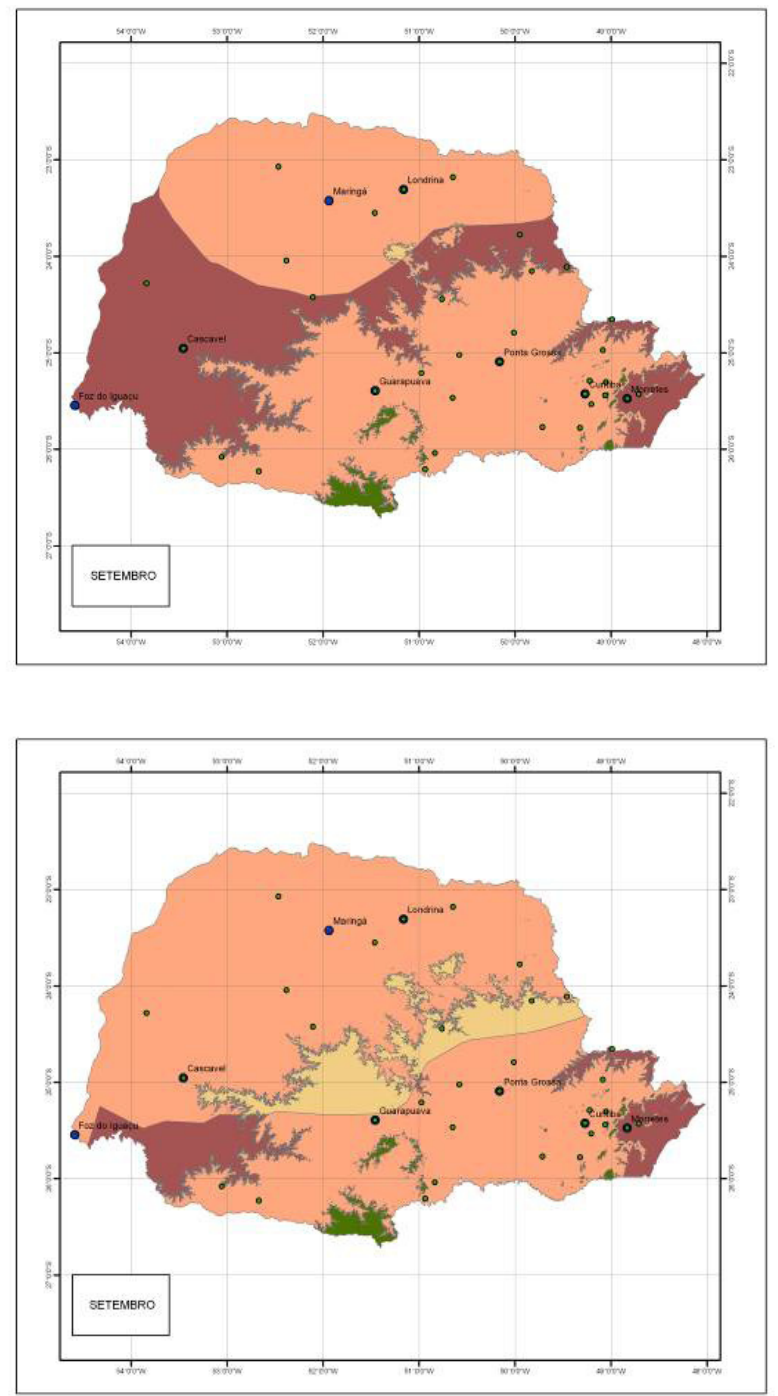

Legenda:

Altamente favorável

Favorável

Pouco favorável

Desfavorável

Figura 9. Favorabilidade climática da ferrugem do eucalipto no estado do Paraná com base na germinação de urediniósporos de Puccinia psidii e infecção sob períodos de molhamento foliar de quatro e seis horas. Setembro. 
Período de molhamento foliar para ocorrência da germinação
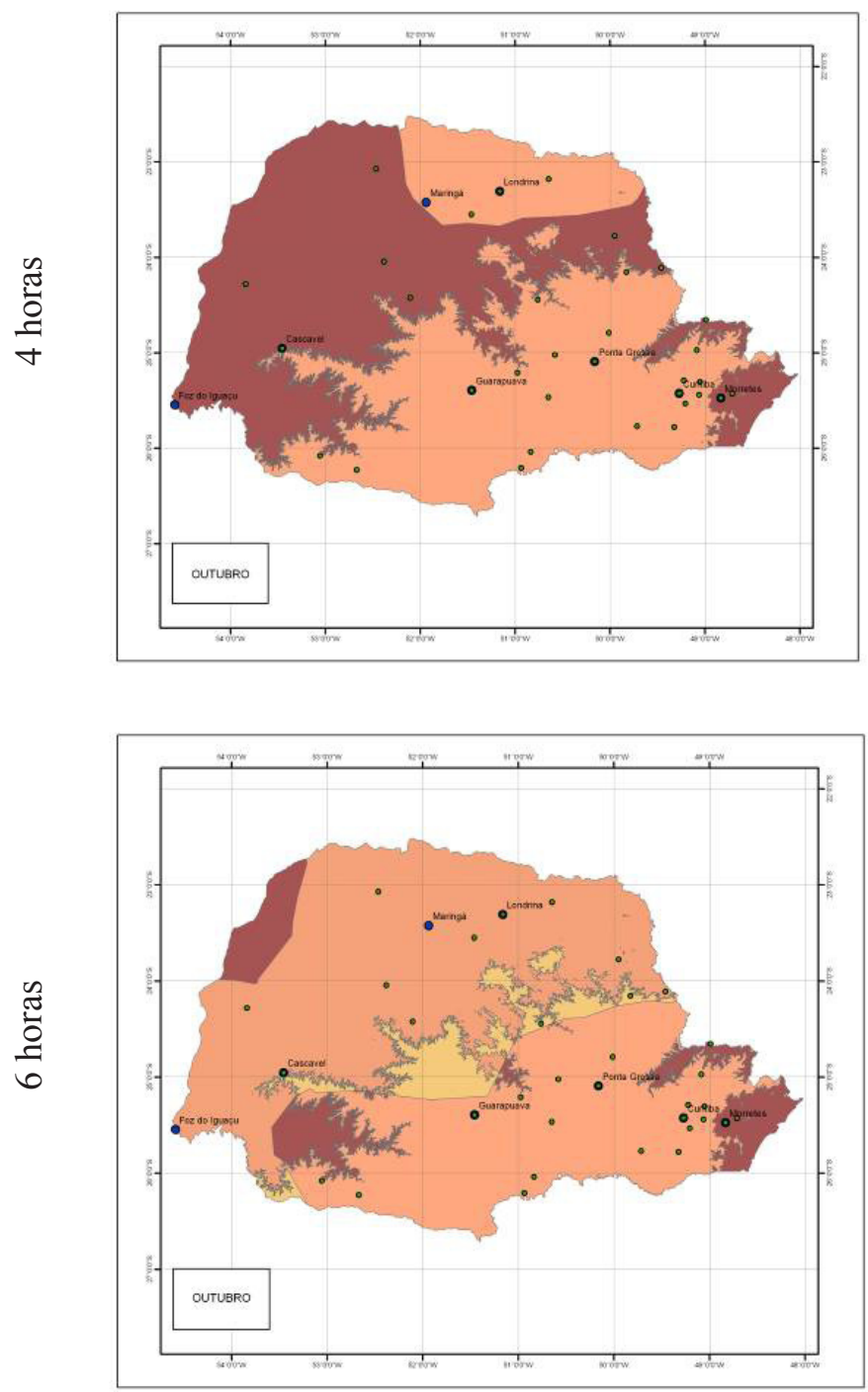

Período de molhamento foliar para ocorrência da infecção
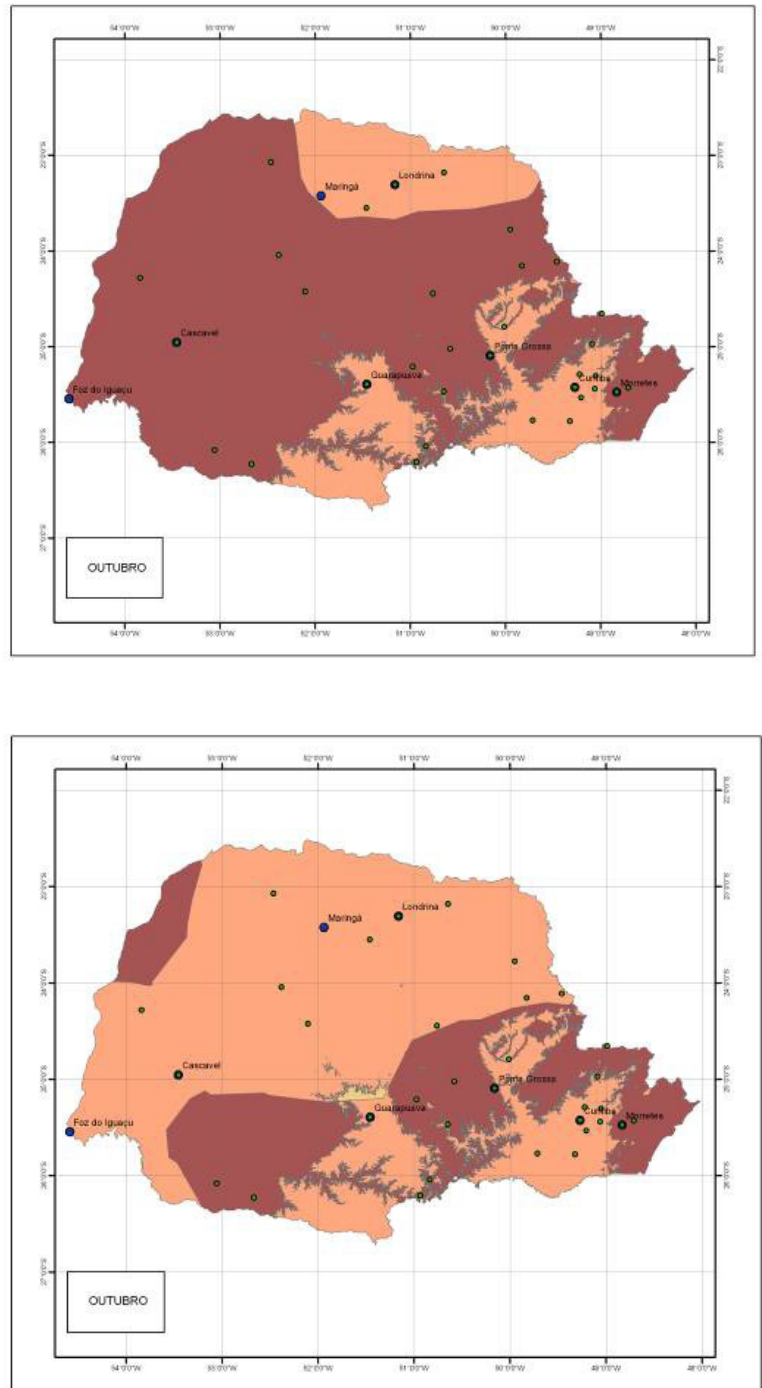

Legenda:

Altamente favorável

Favorável

Pouco favorável

Figura 10. Favorabilidade climática da ferrugem do eucalipto no estado do Paraná com base na germinação de urediniósporos de Puccinia psidii e infecção sob períodos de molhamento foliar de quatro e seis horas. Outubro. 
Período de molhamento foliar para ocorrência da germinação
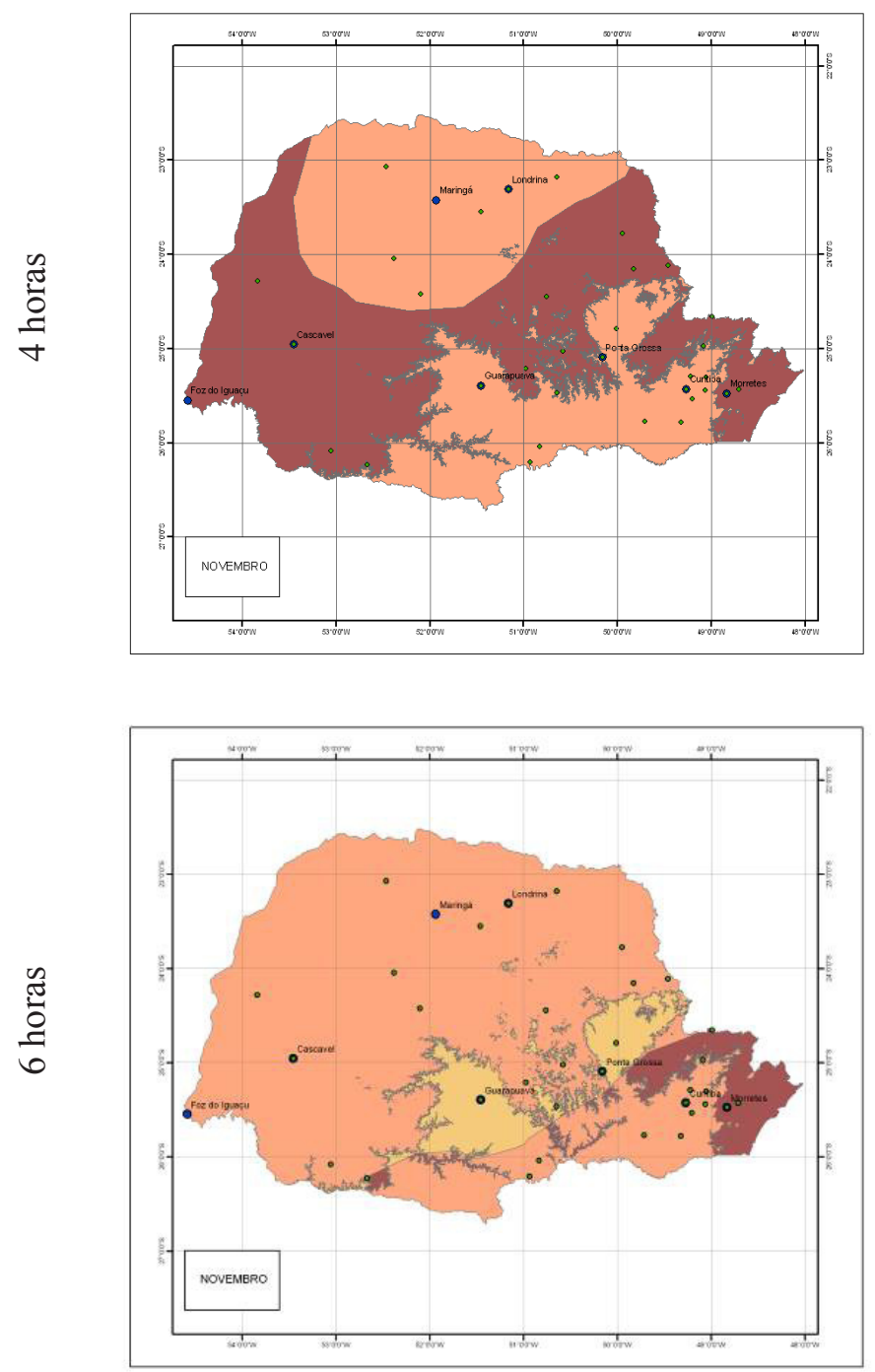

Período de molhamento foliar para ocorrência da infecção
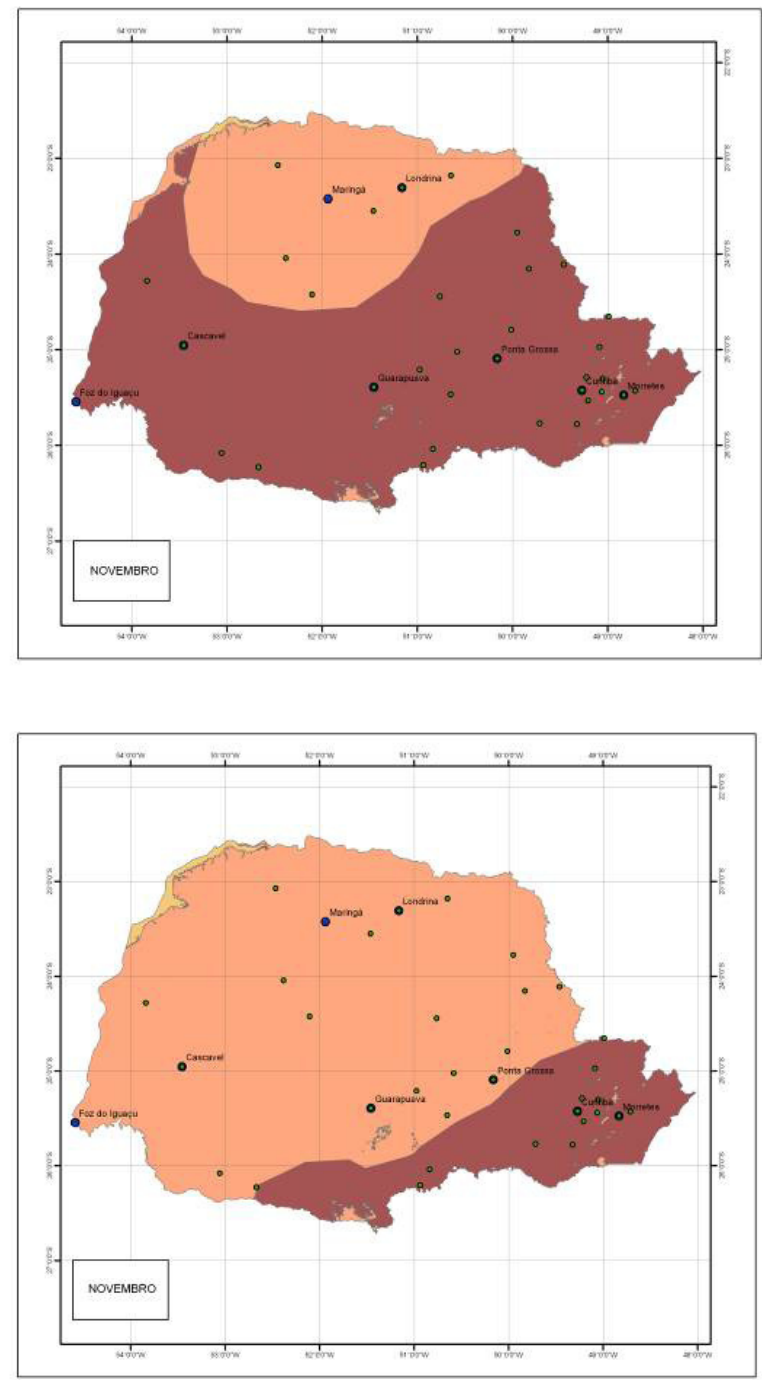

Legenda:

Altamente favorável

Favorável

Pouco favorável

Figura 11. Favorabilidade climática da ferrugem do eucalipto no estado do Paraná com base na germinação de urediniósporos de Puccinia psidii e infecção sob períodos de molhamento foliar de quatro e seis horas. Novembro. 
Período de molhamento foliar para ocorrência da germinação
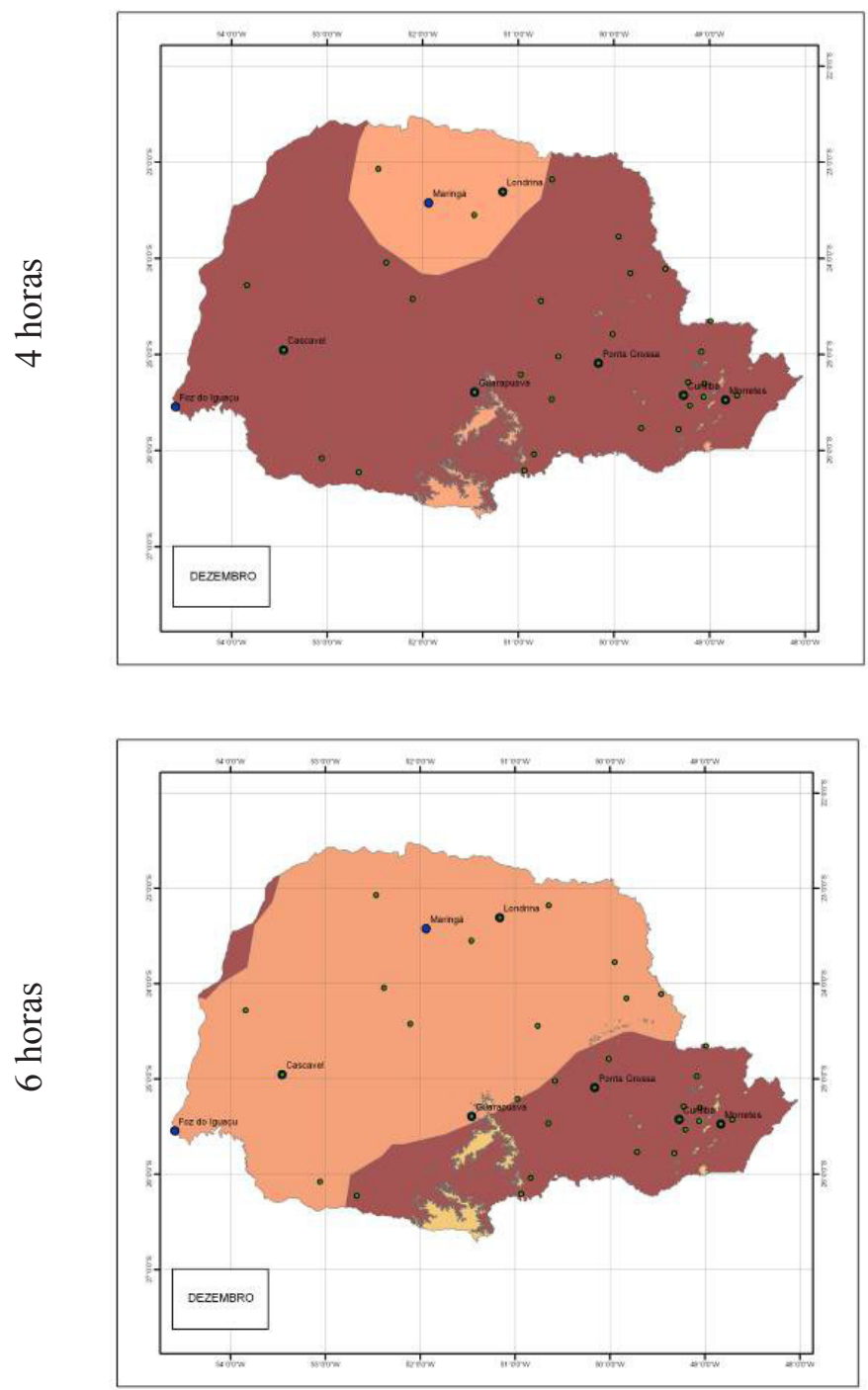

Período de molhamento foliar para ocorrência da infecção
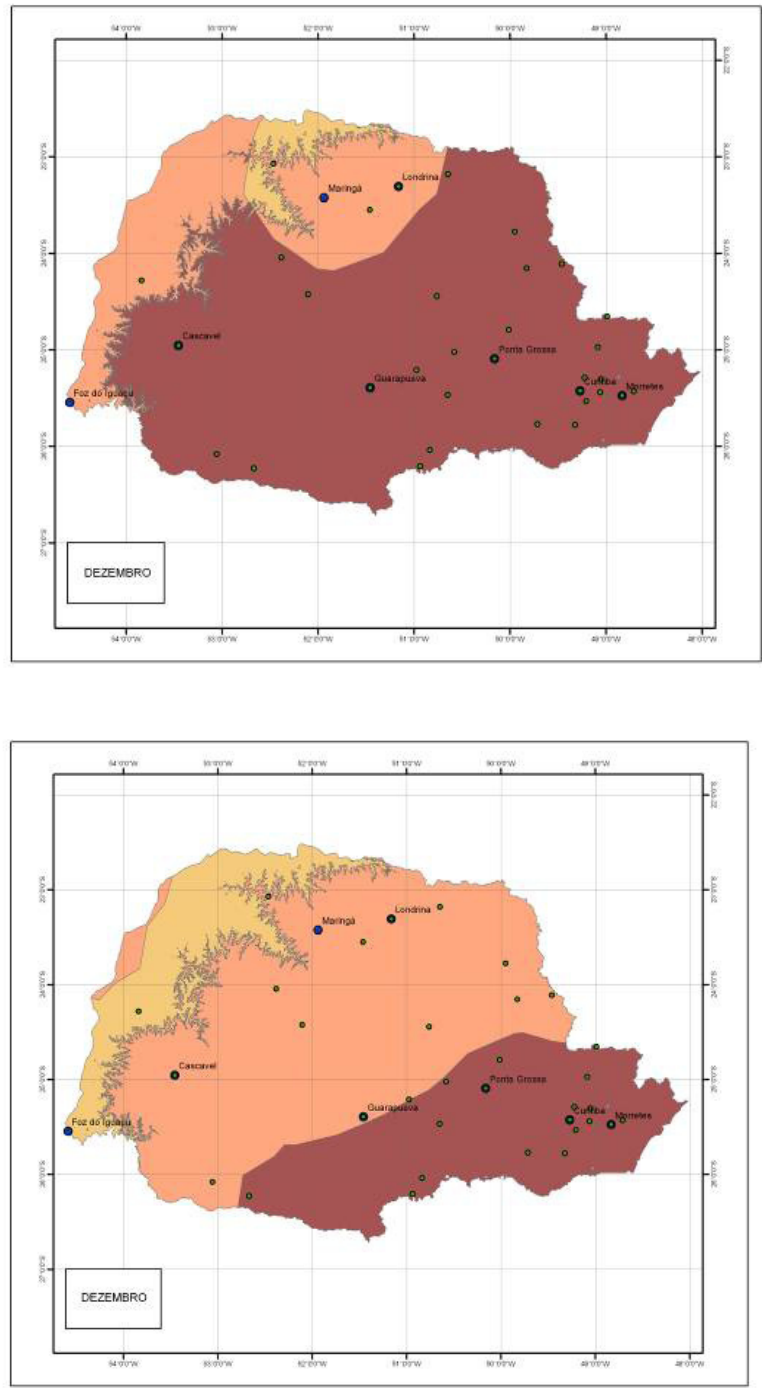

Legenda:

Altamente favorável

Favorável

Pouco favorável

Figura 12. Favorabilidade climática da ferrugem do eucalipto no estado do Paraná com base na germinação de urediniósporos de Puccinia psidii e infecção sob períodos de molhamento foliar de quatro e seis horas. Dezembro. 
Tabela 5. Distribuição mensal de área de favorabilidade (\%) à ferrugem do eucalipto no estado do Paraná utilizando a germinação de urediniósporos de Puccinia psidii em dois períodos de molhamento foliar (quatro e seis horas).

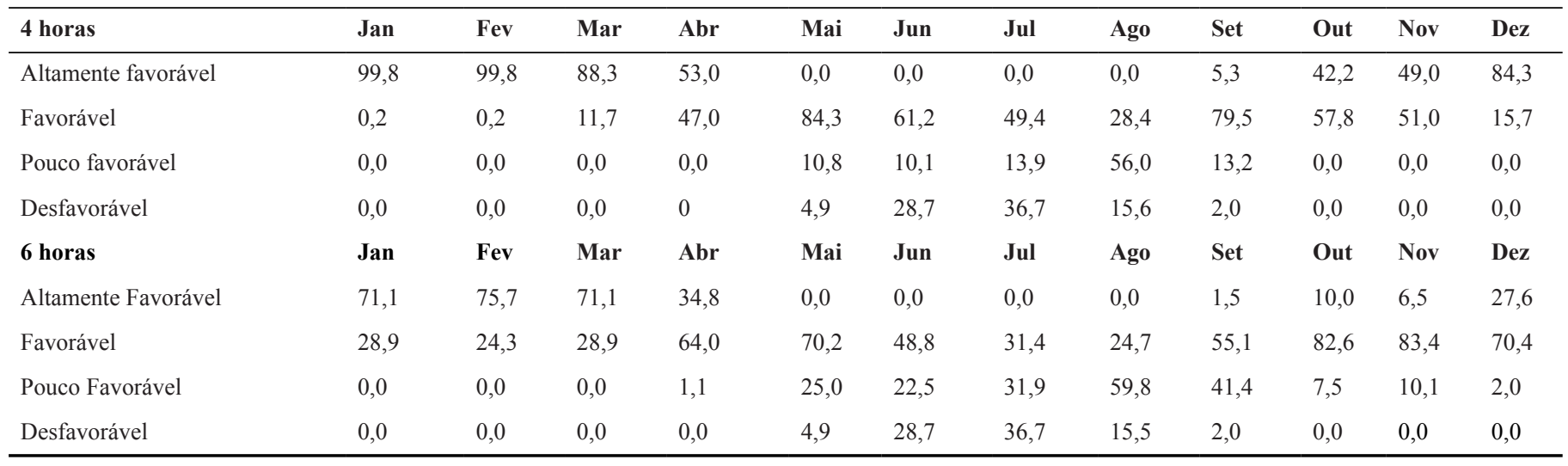

Tabela 6. Distribuição mensal de área de favorabilidade (\%) à ferrugem do eucalipto no estado do Paraná utilizando a infecção de urediniósporos de Puccinia psidii em dois períodos de molhamento foliar (quatro e seis horas).

\begin{tabular}{|c|c|c|c|c|c|c|c|c|c|c|c|c|}
\hline 4 horas & Jan & Fev & Mar & Abr & Mai & Jun & Jul & Ago & Set & Out & Nov & Dez \\
\hline Altamente favorável & 77,6 & 85,9 & 91,0 & 78,4 & 20,5 & 0,8 & 0,9 & 9,1 & 31,0 & 72,9 & 71,3 & 74,2 \\
\hline Favorável & 22,4 & 14,1 & 9,0 & 21,6 & 59,4 & 49,9 & 44,0 & 65,3 & 67,3 & 27,1 & 28,4 & 22,6 \\
\hline Desfavorável & 0,0 & 0,0 & 0,00 & 0,00 & 18,2 & 41,9 & 44,2 & 17,6 & 1,5 & 0,0 & 0,0 & 0,0 \\
\hline 6 horas & Jan & Fev & Mar & Abr & Mai & Jun & Jul & Ago & Set & Out & Nov & Dez \\
\hline Favorável & 27,0 & 24,3 & 26,2 & 40,9 & 62,8 & 38,1 & 27,3 & 48,2 & 81,3 & 71,0 & 80,0 & 57,2 \\
\hline Pouco Favorável & 12,1 & 6,9 & 0,00 & 0,00 & 7,6 & 20,7 & 29,4 & 32,5 & 9,3 & 0,4 & 1,0 & 14,3 \\
\hline Desfavorável & 0,0 & 0,00 & 0,00 & 0,00 & 17,8 & 41,1 & 43,3 & 17,6 & 1,5 & 0,0 & 0,0 & 0,0 \\
\hline
\end{tabular}

regiões com maior percentual de área favorável ao desenvolvimento são apresentadas nos mapas com 4 horas de período de molhamento foliar (Tabela 6), considerando-se todas as classes de favorabilidade.

Assim, pode-se dizer que para a classe 'muito favorável', foi verificada maior área com apenas 4 horas de molhamento foliar. No caso das demais classes, 'favorável' e 'pouco favorável', as maiores áreas foram observadas para 6 horas de molhamento foliar e que não houve diferença entre 4 ou 6 horas de molhamento para a classe 'desfavorável' (Tabela 6).

As condições foram mais favoráveis ainda para a germinação do que para a infecção, quando se analisa a distribuição mensal das áreas de favorabilidade à ferrugem (Tabelas 5 e 6). A umidade favorece a germinação e penetração dos fitopatógenos, bastando um curto período de condição favorável, independentemente da luminosidade (25).

O patógeno $P$. psidii necessita de umidade sobre as folhas e brotações, em condições noturnas, para que os urediniósporos germinem e penetrem na planta hospedeira (9). A umidade, na forma de água livre, pode se apresentar como precipitação pluviométrica, como orvalho nas primeiras horas da manhã ou como neblina à noite. A germinação é o primeiro passo para se iniciar o processo de infecção. Se não houver as condições favoráveis para esse fim, isto é, ocorrerem temperaturas e molhamento foliar, a ferrugem não se estabelece.

Além disso, é necessária a presença de tecidos foliares jovens (21). Desse modo, a utilização do parâmetro infecção deve ser mais adequada por pressupor a existência das condições ambientais favoráveis. O uso das condições favoráveis à germinação de esporos pode ser interessante em estudos preliminares do efeito da temperatura na ocorrência de doenças cujos patógenos ainda não foram estudados.

Booth et al. (3), fazendo estimativas mundiais de risco para P. psidii, consideraram a possibilidade de riscos epidêmicos da ferrugem nas zonas tropicais da América do Sul (mais quentes). Corroborando esta afirmação, no caso do Paraná, apenas algumas zonas de clima mais quente podem apresentar esse risco, entre as quais o Litoral, o extremo Norte e Oeste, nas regiões de menor altitude, situadas nas calhas dos rios Tibagi, Ivaí, Piqueri, Paranapanema e Paraná, principalmente na primavera, no verão e no outono (Figuras 1, 2, 3, 4, 9, 10, 11 e 12). No inverno, com o frio, ocorre redução do risco (Figuras 6, 7 e 8).

$\mathrm{O}$ uso do zoneamento como indicativo das áreas de plantio e das épocas do ano com riscos menores, visando reduzir a ocorrência da ferrugem no eucalipto, deve ser feito em conjunto com a avaliação das espécies/clones de eucalipto a serem plantadas, em função do comportamento diferenciado das espécies de eucalipto quanto à resistência genética ao fungo $P$. psidii $(9,16,22)$.

\section{REFERÊNCIAS BIBLIOGRÁFICAS}

1. Alfenas, A.C.; Zauza, E.A.V.; Mafia, R.G.; Assis, T.F. de. Clonagem e doenças do eucalipto. Viçosa, MG: UFV. 2009. 500 p.

2. Alvares, C.A.; de Mattos, E.M.; Sentelhas, P.C.; Miranda, A.C.; Stape, J.L. Modeling temporal and spatial variability of leaf duration wetness in 
Brazil. Theoretical and Applied Climatology, v. 20, n.3, p455-467, 2015. Disponível em: < http://link.springer.com/article/10.1007/s00704-014-11823>. Acesso em: 27 out. 2015.

3. Booth, T. H.; Old, K. M.; Jovanovic, T. A preliminary assessment of high risk areas for Puccinia psidii (Eucalyptus rust) in the Neotropics and Australia. Agriculture, Ecosystems and Environment, v.82, p.295-301, 2000.

4. Carpanezzi, A. A. (Coord.). Zoneamento ecológico para plantios florestais no Estado do Paraná. Brasília, DF: EMBRAPA-DDT; Curitiba: EMBRAPA-CNPF, 1986. 89 p. (EMBRAPA-CNPF. Documentos, 17).

5. Cria. Centro de referência em informação ambiental. Disponível em: $<$ http:// splink.cria.org.br/geoloc>. Acesso em: 14 abr. 2014.

6. Crop Protection Compendium. Datasheet: Puccinia psidii. Disponível em: $<$ http://www.cabi.org/cpc/datasheet/45846>. Acesso em: 24 abr. 2014.

7. Cruz, K.R.O.; Santos, A.F. dos; Auer, C.G. Efeito de diferentes temperaturas na germinação de urediniósporos de Puccinia psidii. In: Evento de iniciação científica da Embrapa Florestas, 8., 2009, Colombo. Anais. Colombo: Embrapa Florestas, 2009. 1 CD-ROM. (Embrapa Florestas. Documentos, 186). Evinci. Resumo.

8. Ferreira, F.A. Ferrugem do eucalipto. Revista Árvore, Viçosa, v.7, n.2, p, 104, 1983.

9. Ferreira, F.A. Patologia Florestal; principais doenças florestais no Brasil. Viçosa: SIF, 1989. 570p.

10. Furtado, E.L. Ecologia de Puccinia psidii e impacto na produção de eucalipto no Brasil. Fitopatologia Brasileira, Lavras, v.31, suplemento, p.49-52, 2006.

11. Furtado, E.L.; Dias, D.C.; Ohto, C.T.; Rosa, D.D. Doenças do eucalipto no Brasil. Botucatu: FEPAF, 2009. 74p.

12. Hamada, E.; Ghini, R.; Fernandes, J.L.; Pedro Júnior, M.J.; Rossi, P. Spatial and temporal variability of leaf wetness duration in the State of São Paulo, Brazil. Scientia Agricola, Piracicaba, v.65, special issue, p.26-31, 2008.

13. Ibá. Indústria Brasileira de Árvores. Relatório Ibá 2015. Brasília: Ibá. 80p. Disponível em: <http://www.iba.org.br>. Acesso em: 27 out. 2015.

14. Masson, M.V.; Ohto, C.T.; Furtado, E.L.; Silva, S.A. Zoneamento climático do eucalipto no Estado de São Paulo visando o controle da ferrugem. Summa Phytopathologica, Botucatu, v.33, suplemento, p.67, 2007.

15. Masson, M.V. Ferrugem do eucalipto: planejamento evasivo, estimativa de dano e análise da viabilidade do controle químico. $167 \mathrm{f}$. Botucatu. Dissertação (Mestrado em Agronomia - Proteção de plantas), Universidade Estadual Paulista "Júlio de Mesquita Filho", Faculdade de Ciências Agronômicas. Botucatu, 2009.

16. Moraes, W.B., Jesus Júnior, W. C. de, Mafia, R.G., Moraes, W.B.; Cecílio, R.A. Mapeamento de áreas de risco para ocorrência da ferrugem do euca- lipto no Espírito Santo e extremo sul da Bahia. Summa Phytopathologica, Botucatu, v.40, n.2, p.147-155, 2014. Disponível em: <http://www.scielo. br/scielo.php?script $=$ sci arttext\&pid=S0100-54052014000200007\&lng= pt\&nrm=iso $>$. Acesso em 27 out. 2015.

17. Morin, L.; Aveyard, R.; Lidbetter, J.R.; Wilson, P.G. Investigating the host-range of the rust fungus Puccinia psidii sensu lato across tribes of the family Myrtaceae present in Australia. PLoS One. v.7, n.4, p.:e35434. doi:10.1371/journal.pone.0035434.

18. Paludzyszyn Filho, E.; Santos, P.E.T. dos; Ferreira, C.A. Eucaliptos indicados para plantio no Estado do Paraná. Colombo: Embrapa Florestas, 2006. 45 p. (Embrapa Florestas. Documentos, 129).

19. Piza, S.M.; Ribeiro, I.J.A. Influência da luz e da temperatura na germinação de uredosporos de Puccinia psidii. Bragantia, Campinas, v.47, p.75-78, 1988.

20. Ruiz, R.A.R. Epidemiologia e controle químico da ferrugem (Puccinia psidii Winter) do eucalipto. 108f. Viçosa - Minas Gerais. Dissertação (Mestrado em Agronomia), Universidade Federal de Viçosa. Viçosa, 1988.

21. Ruiz, R.A.R.; Alfenas, A.C.; Ferreira, F.A.; Vale, F.X.R. Influência da temperatura, do tempo de molhamento foliar, do fotoperíodo e da intensidade de luz sobre a infecção de Puccinia psidii em eucalipto. Fitopatologia Brasileira, Brasília, v.14, n.6, p.55-61, 1989.

22. Silva, P.H.M.; Miranda, A.C.; Moraes, M.L.T.; Furtado, E.L.; Stape, J.L.; Alvares, C.A.; Sentelhas, P.C.; Mori, E.S.; Sebbenn, A.M. Selecting for rust (Puccinia psidii) resistance in Eucalyptus grandis in São Paulo State, Brazil. Forest Ecology and Management, Amsterdam, v.303, p.91-97, 2013.

23. Stammer, E.E.; Tomaz, R. Ocorrência de fungos e bactérias fitopatogênicas no Estado do Paraná. Curitiba: Secretaria do Estado da Agricultura e do Abastecimento/DEFIS/Centro de Diagnóstico Marcos Enrietti. 1991. 91p.

24. United States Geological Survey - Survey National Mapping Division. Global 30 Arc Second Elevation Data. 1999. Disponível em: <https:// lta.cr.usgs.gov/GTOPO30>. Acesso em: 28 out. 2015.

25. Vale, F. X. R. do; Zambolim, L.; Costa, L. C.; Liberato, J. R.; Dias, A. P. S. Influência do clima no desenvolvimento de doenças de plantas. In: Vale, F. X. R. do; Jesus Junior, W. C. de; Zambolim, L. (Ed.) Epidemiologia aplicada ao manejo de doenças de plantas. Belo Horizonte: Editora Perfil, 2004, cap. 2, p. 47-87.

26. Wrege, M.S.; Steinmetz, S; Garrastazu, M.C.; Reisser Junior, C.; Almeida, I.R. de; Herter, F.G.; Caramori, P.H.; Radin, B.; Matzenauer, R.; Braga, H.J.; Prestes, S.D.; Cunha, G.R.; Maluf, J.R.T.; Pandolfo, C. Atlas Climático da Região Sul do Brasil: Estados do Paraná, Santa Catarina e Rio Grande do Sul. 1. ed. Pelotas: Embrapa Clima Temperado ; Colombo: Embrapa Florestas; 2011. 333 p. 